\begin{tabular}{ccc} 
Coğrafi Bilimler Dergisi & Coğrafi \\
Bilimiler & Dergisi & Turkish Journal of Geographical Sciences \\
\hline
\end{tabular}

\title{
Kentsel Mekânda Kültürel Kimliğin Yeniden Üretimi: Ankara'daki Kültür Merkezleri Örneği ${ }^{1}$
}

\author{
Reproduction of Cultural Identity in Urban Space: The Case of Cultural Centers \\ in Ankara
}

\section{Nurettin Özgen ${ }^{\mathrm{a}}$, Volkan İdris Sarı ${ }^{\mathrm{b} *}$}

\begin{tabular}{l} 
Makale Bilgisi \\
\hline Araştırma Makalesi \\
\hline DOI: \\
10.33688/aucbd.862332 \\
\hline Makale Geçmişi: \\
Geliş: 16.01.2021 \\
Kabul: 02.02.2021 \\
\hline Anahtar Kelimeler: \\
Mekân \\
Kültür \\
Şehir \\
Kimlik \\
Ankara \\
\\
\hline Article Info \\
\hline Research Article \\
\hline DOI: \\
10.33688/aucbd.862332 \\
\hline Article History: \\
Received: 16.01 .2021 \\
Accepted: 02.02.2021 \\
\hline Keywords: \\
Space \\
Culture \\
Identity \\
Ankara \\
\hline
\end{tabular}

\section{$\ddot{O} z$}

Çalışmanın amacı yerel yönetimlerin kentsel alandaki kültürel üretimlere ilişkin pratiklerini, kültür merkezlerinin isimlendirilmesi ve buralarda yürütülen faaliyetler üzerinden analiz etmektir. İktidarlar kurumsal ve ideolojik çerçeveleri kullanarak insanların düşüncelerini ve yaşam tarzlarını etkilerler. Bu etkileme ulusal düzeyde yürütüldüğ̈̈ gibi yerel ölçekte farklı ideolojiye sahip belediyeler tarafindan da hayata geçirilebilmektedir. Hemen tüm siyasi partilere mensup belediyeler kendi ideolojik yaklaşımlarını çeşitli araçlar ile topluma kabul ettirerek kentsel mekânda kimlik inşa sürecini yürütmektedir. Belediyelere bağll olarak hizmet veren kültür merkezleri de kentsel kimlik inşa sürecinin önemli araçlarındandır. Araştırmada, kültür merkezi yöneticileri ve kursiyerleriyle yapılan görüşmelerle elde edilen nitel veriler içerik analizi tekniği kullanılarak derinlikli bir şekilde analiz edilmiştir. Araştırma sonucunda hem bu mekânlar için tercih eden isimler hem de burada yürütülen faaliyetlerin kentsel kimliğin üretimi ve yeniden üretiminde belediyeler tarafindan etkin bir şekilde kullanıldı̆̆ı anlaşılmıştır.

Abstract
The aim of this study is to analyze the practices of local governments
regarding cultural production in the urban area through naming cultural
centers and the activities carried out in these centers. Powers influence
people's thoughts and lifestyles using institutional and ideological
frameworks. This influence can be carried out at the national level as well as
by municipalities with different views at the local level. Municipalities
belonging to almost all political parties carry out the identity building process
in the urban space by imposing their ideology and approach to the society
through various tools. Cultural centers serving under local governments have
also been one of the important tools of the urban identity building process.
Within the scope of the research, the qualitative data obtained through
interviews with cultural center managers and visitors were analyzed in depth
using the content analysis technique. As a result of the research, it was
understood that both the names that preferred for these spaces and the
activities carried out here were used effectively by local governments in the
production and reproduction of urban identity.

\footnotetext{
*Sorumlu Yazar/Corresponding Author: Volkan İdris Sarı, volkan.i.sari@gmail.com

a Ankara Üniversitesi, Dil ve Tarih Coğrafya Fakültesi, Coğrafya Bölümü, Ankara/Türkiye, http://orcid.org/0000-0001-9191-1579.

b Ankara Üniversitesi, Sosyal Bilimler Enstitüsü, Ankara/Türkiye, http://orcid.org/0000-0001-7032-8069.

${ }^{1}$ Bu makale, Koç Üniversitesi VEKAM 2019 Araştırma Ödülü’ne hak kazanan, "Siyasal İdeolojiler Bağlamında Mekân İsimlendirmeleri: Ankara'daki Kültür Merkezleri Örneği” adlı araştırma projesine dayandırılarak hazırlanmış olup, söz konusu araştırmanın sonuçlarını ortaya koyan bir makale Ankara Araştırmaları Dergisi'nde Haziran 2021 sayısına yayınlanmak üzere kabul edilmiştir.
} 


\section{Giriş}

Kültür merkezleri, kültürün yeniden üretildiği yaygın eğitim-öğretim kurumlarıdır ve aynı zamanda, iktidarlar tarafından özenle dizayn edilen ideolojik mekânlardır. Kültürel etkinliklerin ideolojik saiklerle vatandaşlara/katılımcılara aktarıldığı bu mekânlara hangi ismin verileceğinden, ne tür etkinliklerin yürütüleceğine kadar, tüm kararlar bahse konu kültür merkezinin bağlı olduğu belediye meclisinin oy çokluğu ile başlar ve ilgili siyasal hiyerarşiye göre şekillenir. Çoğunluğa sahip siyasal grup/parti, ideolojik bir misyonla kendi kültürel kodlarına uygun etkinlikleri hayata geçirir ve kültür merkezinin isimlendirilmesi de aynı bağlamda örülür. Bu pratiklerle iktidarın kentsel-kamusal alandaki görünürlüğü arttığı gibi, toplumsal hafızanın inşasında da daha çok yer almış olur.

İnsan belleği geçmiş deneyimlerini kaydederken mekâna ihtiyacı vardır ve olayları mekânsallaştırma eğilimindedir (Köşker, 2018: 89). Esasında aynı durum toplumsal bellek için de geçerlidir. Mekâna ilişkin deneyim ve yaşanmışlıklar toplumsal bellekte tutulur ve bunlar zamanla oluşan kimlikler vasıtasıyla mekânın yeniden üretiminde ortaya çıkar. Bu bağlamda, insanların hafızası olduğu gibi toplumların ve kentlerin de hafızası vardır. Bu hafızanın devamlılığını sağlayan gerek soyut gerekse somut birçok araç bulunmaktadır. Hafiza geçmişle ilgili olsa da esasında günümüzde gerçekleşen bir süreçtir (Mills, 2014: 47). Bu süreçte geçmişe ait unsurlar bazen bağlamı ile bazen bağlamından kopuk bir şekilde seçilerek günümüze taşınır.

Toplumsal bellek; zaman, mekân ve tarihsel koşullara bağlı olarak sürekli güncellenir (Şekil 1). $\mathrm{Bu}$ anlamda anılar, dil, geçmiş ve kültür, toplumların kolektif belleğini etkileyen unsurlardır. Kentsel mekânlar kendine has özellikleri ile bu unsurların yaşanmasını ve kendini yenilemesini sağlamaktadır. Böylelikle kentsel bellek, mekândaki değişimlere bağl1 olarak sürekli değişim ve dönüşüm sağlamakta (Ünlü, 2017: 78) ve bu mekânda yaşayanları diğerlerinden ayıran kimlik unsurlarını ortaya çıkarmaktadır.

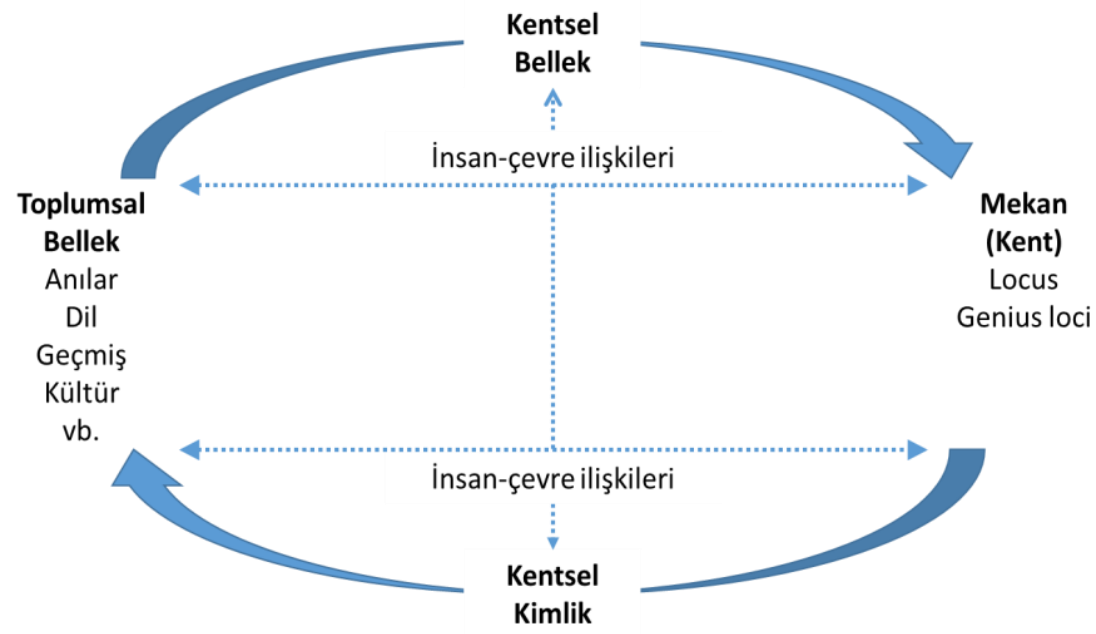

Şekil 1. Kentsel bellek-mekân ve kentsel kimlik ilişkisi Kaynak: Ünlü, 2017: 78

Kültür ile mekân arasında yakın ve güçlü bir simbiyotik ilişki vardır. İnsan davranışları üzerinde belirleyici bir role sahip olan kültür, mekânı etkileyerek bir sosyal inşa sürecini başlatır. Köşker'in (2018: 87) ifadesiyle "kültür, insanın kendisi için mekânı uyarlaması ve mekâna uyarlanması 
sonucunda biriktirdiği her şeydir”. Bir başka ifadeyle kültür, kimliğin en önemli kaynağıdır. Zaman içerisinde belirli bir mekâna karşı geliştirilen aidiyet ve sahiplenme duygusu karşılıklı olarak hem o mekâna hem de onu sahiplenen bireylere bir kimlik kazandırır. Dolayısıyla mekânın inşa süreci doğrudan kültürle ilişkilidir.

$\mathrm{Bu}$ anlamda, fiziki mekân sembolik anlamlardan arınmış boş bir mekân olmayıp, doğru bir şekilde okunabilmesi için kültürel gözlüklere ihtiyaç vardır (Öncü ve Weyland, 2016: 31). Kültür ise insanlar ve toplumlar tarafından kendine has bir şekilde biçimlenir ve bu kendine has nitelikler mekâna bireysel ve toplumsal kimliği yansıtır. Bu nedenle kentsel kimlik, kentsel faaliyetler ve işlevler ile fiziki çevrenin bütünlüğüne ilişkin bir unsurdur. Bu bağlam üzerinden, bir yerin kimliğinin oluşma süreci genel olarak tarihsel bir olgudur (Tekeli, 2009: 84). Böyle bakıldığında mekân çeşitli sembollerle belirli kimlik ve anlamlar kazanır. Ayrıca toplumda baskın olarak kullanılan söylemler de toplumsal yaşamı doğrudan ve dolaylı şekillerde etkilemektedir (Günay-Aktaş ve Yayla, 2018: 241). Dolayısıyla toplumsal bellek iktidarın güç mücadelelerini verdiği bir alandır ve resmî ideoloji ya da söylemler vasitasiyla, hatırlatmak ya da unutturmak istediklerini tayin eder.

Buna bağlı olarak kentsel kimlik oldukça tartışmalı bir kavram olup, bu kavram dile geldiğinde/getirildiğinde bir toplumsal çatışma da söz konusu olmaktadır (Bauman, 2017: 95). Bunun nedeni toplumdaki tüm çeşitliliğe rağmen sadece bir ya da birkaç kimliğin öne çıkması ve bunun tüm toplum kesimlerini temsil edememesidir. Sonuçta kimlik tartışmaları belirli bir toplum kesimini birleştirdikçe, aynı zamanda diğerleri ile ayrıştırma görevi görür. Kimliğin birleştirici ve ayrıştırıcı işlevleri aynı anda ve eş zamanlı olarak yürür (Bauman, 2017: 97). Bu bağlamda kimlik kavramı iki temel sürecin etkileşimi ile ortaya çıar: birincisi benzerliklerin tanımlanması ve ortaya konulması anlamında içşel pekiştirme, ikincisi ise ötekilerden farklılıklar üzerinden bir dışsal ayırt etmedir (Özgen, 2018:113). Dolayısıyla kimlik içermenin ve kapsayıcılığın olduğu kadar dışlamanın ve ayrımcılığın da bir aracıdır. Bu tanımlama birey, toplum ve kent üzerinden okunabilir. Farklılıkları aynı mekânda buluşturan kentler bünyesinde çok çeşitli çelişkiler taşır, bu çelişkiler mekânda yeniden üretilir ve ayrışma mekânlarını oluşturur (Aliağaoğlu ve Uğur, 2016: 217).

Kent, somut ve somut olmayan birçok unsur üzerinden kendi kimliğini geliştirir (Madanipour, 2013: 52). Yer ve mekân isimlerini kapsayan kentsel toponimi de kentin somut olmayan kimlik unsurlarından birisidir (Baysan, 2019: 281). Yer ve mekân adları kente dair değişim ve dönüşüm süreçlerinin okunabildiği araçlardır. Zira toplumsallaşma sürecinde bireyler, çevresini sembolik olarak algılamayı ve benimsemeyi öğrenir. Bu süreç ona isim vermeyle sonuçlanır ve isimlendirmeyle çevreyi, kimliğinin bir parçası haline dönüştürür (Mai, 2016: 112). Yer isimleri yalnızca coğrafyayla geçmişi birleştirmekle kalmaz, aynı zamanda gündelik olarak kullanılarak ve atıfta bulunularak kent ve toplum kimliğinin oluşmasında da rol oynar. Mekân isimleri görünüşte basit birer tercih gibi görünse de aslında kendine o ismi veren kültürlerin değerlerini, inançlarını, özlemlerini, acılarını, sevinçlerini, kısacası tüm yaşanmışlıklarını yansıtır (Gülbetekin, 2017: 32). Bugün tarih sayfasından silinmiş toplumların bile koymuş olduğu isimler halen kullanılabilmektedir. O nedenle yer isimleri birikimli bir şekilde tarihsel süreci de taşıma görevi üstlenir. Mekân isimleri bu anlamda toplumsal hafizayı canlı tutar ve yaptığı çağrışımlar ile hafızaları tazeler. Dolayısıyla, zaman içerisinde kullanılan isimler ve bunların sürekliliği toplumsal belleğin oluşmasına katkıda bulunur. Kentsel ölçekte ise kentin yaşadığı önemli kırılma 
noktaları, güncel politikalar, kent belleğinde yer etmiş kişiler ya da olaylar ile kentsel kimliğin oluşmasında etkili olan öğeler, isimlendirmeler üzerinden okunabilir (Araz, 2015: 97). Kültür coğrafyasının diğer unsurları ile karşılaştırıldıklarında ise mekân isimlendirmeleri, günlük hayatta sürekli tekrar edilmeleri nedeniyle kentsel kültürün yeniden inşasına önemli bir katkı sağlamaktadır.

Lynch (2010: 120), yerleşim alanlarını oluşturan fiziksel özellikleri tarif eden kentsel formun 10 temel niteliğinden bahsetmektedir. Bunlardan birisi de isimler ve anlamlardır. Lynch, isimlerin ve anlamların kimliği belirginleştirdiğini ve fiziksel yapı içerisinde gizli unsurları güçlü bir şekilde açığa çıkarabildiğini belirtmiştir. Çünkü kentin özgün bir kimlik edinebilmesi için kentlilerin onu bilmesi ve sahiplenmesi, ona aşina olması, ortaya çıkışı, değişimi ve dönüşümüne aktif olarak katılması gerekmektedir (Bilgin, 2011: 40).

Kültürün hem birleştirici hem de ayrıştırıcı özelliği (Tümertekin ve Özgüç, 2019: 163) yer isimleri için de geçerlidir. Mills (2014: 52) şehirleri "hatırlama ve unutuşun gerçekleştiği alan ve bunu sağlayan araç” olarak tanımlamaktadır. Yer adları ile mekân isimleri ise bu araçların en önemlileri arasındadır. İsimlendirme; kültürel kimliğin inşası, yaşatılması ya da isim değişiklikleri ile inşa edilmiş bir kimliğin sönümlendirilmesi de mümkün olmaktadır. Kentsel belleğin istenmeyen kısımlarının unutturulması, yerine başkalarının konması genellikle yer isimlendirmeleri üzerinden yapılmaktadır (Köşker, 2018: 92). Sokağa, caddeye veya meydana verilen isim ya da değiştirilen bir isim, bir anıy1 unutturma ya da tarihin yeniden kurgulanmasına yardımcı olmaya hizmet etmektedir (Araz, 2015: 30). $\mathrm{Bu}$ iki eylem de iktidar tarafından kontrol edilebilmekte ve buna bağlı olarak yerin kimliği siyasal iktidarın söylemleri ile inşa edilmektedir (Köşker, 2018: 91). Diğer tüm hatırlama unsurları kaybolmuş, orada yaşayan insanlar yok olmuş olsa bile yer isimleri bir yerin tarihi ve geçmişi hakkında bize çok şey hatırlatır (Tümertekin ve Özgüç, 2019: 184). Dolayısıyla mekân isimleri kentsel kültürel kimliğin dünü, bugünü ve yarını için önemli unsurlardır.

Bu bakımdan mekân isimleri kültürlerin dışavurumudur ve söz konusu toplum için bir kültürel temsil işlevi görmektedir. İsimlendirme tercihleri ile kültürel bir tercih yapılmış olmakta ve o mekân, söz konusu kültür ile özdeşleştirilmektedir. Diğer bir ifadeyle, bir mekânın adlandırılması esasında onun kategorize edilmesidir. Bir kez isim verildikten sonra mekânın fiziki yapısı, mimarisi, içinde cereyan eden faaliyetler ile birlikte ismin kendisi de bir kültür üyesi olur, ayrı bir kimlik kazanır (Gülbetekin, 2017: 69). Bu nedenle mekânın adlandırılması her daim ideolojik üretimlere açıktır (Özgen, 2018:117). $\mathrm{Bu}$ ideolojik üretimler, aslında iktidarın kendi etki alanını konsolide eden ve hatta geliştirerek yeniden üretim stratejisine dayanan pratiklerdendir. Hiç şüphesiz bu yapısalcı üretim stratejisini, post-yapısalcı yaklaşım gibi farklı bakış açılarıyla analiz eden yaklaşımlar da mevcuttur. Bu bağlamda postyapısalcılar, bireysel konuşmacıların ya da yazarların niyetleri, inançları veya algılarından öte, söylemsel yapı ve özellikleri, belirli bir yazımı ya da konuşmayı doğal ve güvenilir yapan söylem biçimlerini incelerler (Ar, 2020: 282). Temsili pratiklerde dışarıda bırakılan öteki dünyaların tasavvur edilebilmesi için hâkim söylemleri doğallaştırılmış hallerinin ötesinde görmeyi amaçlarlar. Dahası, çeşitli söylemsel yapıların hangi süreçlerle inşa edildiği, sabitlendiği ya da değiştirildiğiyle alakadar olurlar (Aydın-Düzgit, 2015: 156). 
Post-yapısalcılık, dil ve anlamın farklı şekillerde tezahür ettiğini ileri sürer. Bu bağlamda, iktidar ve güç ilişkilerinin bilgiyi ve söylemi belirleyerek toplumsal hayatın tüm süreçlerine nasıl nüfuz ettiği değerlendirilir. Onlara göre anlamın merkeziliği yoktur. Dolayısıyla yapının metin ya da söylemlerde, doğrudan veya dolaylı şekilde inşa ettiği, farklı aygıtlar aracıllğıyla ürettiği anlamların, bilişsel ya da duyuşsal formda ve tekdüze bir biçimde karşılık bulması olanaklı değildir. "İnsan öznesinin bütüncül bir bilince sahip olmadiğını ve temelde dil yoluyla yapılandı̆̆ını savunan post-yapısalcllık, nedensellik, özdeşlik, ikicilik ve doğruluk gibi kavramları da sıkı bir eleştiri süzgecinden geçirir” (Cevizci, 1999). Olgular için tekil anlamın söz konusu olmaması, bu anlamın zamana ve mekâna göre farklılaşması ve katı bir biçimde yüklenen anlamların gerçekliği tam olarak yansıtmaması bu tespitin temel gerekçesidir (Bilgili, 2017: 102). Dolayısıyla post-yapısal yaklaşıma göre herhangi bir söylem veya metnin anlamını tekleştiren bir gerçeklik veya sınırlayan, geleneksel, merkezi bir anlam yoktur. Çünkü anlam kavramı, sınırı ve formu tam olmayan ya da belirli form ve süreç içinde tanımlanamayan demektir. Anlamın kesin, mutlak, katı ve statik olduğuna karşı yaklaşımdan uzaktır (Parkes, 2012:1-2). Bir metni ya da söylemi yorumlayan kişiye göre değişen çok boyutlu anlamı ifade eder.

$\mathrm{Bu}$ çerçevede en çok kullanılan araçlardan birisi de tercih edilen isimlerin analiz edilmesidir. Yer isimlerinin yapı, anlam ve köken bakımından incelenmesi (Eren, 1966: 155) anlamına gelen toponimi, belirli bir yerdeki insanların ve onların kültürleri hakkında çok değerli bilgiler sunmaktadır (Tümertekin ve Özgüç, 2019: 183). İsimlendirme çalışmaları genellikle dilbilimsel açıdan incelenme eğiliminde olup, bu alanda farklı bakış açıları eleştirel toponimi çalışmaları ile gündeme gelmiştir.

Eleştirel toponimi, isim verme tercihlerini dilbilimsel yaklaşımın ötesinde iktidar ilişkilerini yansitan bir eylem olarak görmektedir (Özberk, 2018: 666). Eleştirel coğrafya, mekânsal toponimiyi toplumsal eşitsizliklerin, baskı araçlarının ve toplum mühendisliğinin bir parçası olarak görme eğilimindedir (Alderman ve Inwood, 2013). Turan ve Yalçıner-Ercoşkun (2017: 59)'a göre eleştirel toponimi çalışmaları iki bakımdan ele alınabilir. İlki yer isimlerinin topluma neyi ifade ettiğinin ve hatırlattı̆̆ının incelenmesidir. İkincisi ise anlam ve hatırlatma pratiğinin arka planda işleyen siyasi güç ve politik mücadelelerin araştırılmasıdır. Rose-Redwood vd. (2009: 458) ise eleştirel kentsel toponimi analizleri için kullanılabilecek üç farklı teorik çerçeve önermektedir: politik göstergebilim (örn. ülkelerin kurucu babalarının isimlerinin sıklıkla kullanılması), yönetimsellik çalışmaları (numaratik sokak isimlendirmeleri) ile sosyal adalet ve sembolik direnişin normatif teorileri (Amerika'da siyahi direnişin sembol isimlerinin kullanilması gibi).

Türkiye'de eleştirel toponimi çalışmaları sınırlı olmakla birlikte mevcut çalışmaların neredeyse tamamı sokak, cadde, bulvar ve meydan isimlerine yoğunlaşmıştır. Bununla birlikte başta köyler olmak üzere değiştirilen yer adları (Şahin, 2010) ya da kentsel dönüşüm projeleri sonrası oluşan mekânlar (Çetin ve Şentürk, 2019) üzerine de çalışmalar yapıllmıştır.

Bu çalışmada literatürdeki bazı temel çalışmalardan farklı olarak yerel yönetimlerin hizmet alanı içerisinde yer alan kültür merkezlerinin isimlendirme tercihleri ile kültür merkezlerinde yürütülen faaliyetler arasındaki ilişkiler analiz edilmektedir. Zira mekân isimleri, yerel kimlik ve kültüre ait önemli ipuçları taşımaktadır. Dahası yerel yönetimlerin kültürel kimlik inşa süreçleri sadece isim tercihleri ile sınırlı değildir. İsim tercihleri bu sürecin başlangıç noktasını ve mihenk taşını oluşturmaktadır. Kültür 
merkezlerinin kampüslerindeki diğer kullanımlar ve bu merkezlerde sergilenen etkinlikler, kültürel kimliğin yeniden inşası ve yaygınlaştırılması açısından önemli diğer pratiklerdendir (Özgen ve Sarı, 2021). Bu bağlamda, "kültür merkezlerinin isimlendirilmesi ve gerçekleştirilen etkinlikler aracılığıyla iktidarın kültürel yeniden üretiminin nasıl işlerlik kazandığına ilişkin veri ve gözlemlere dayalı analizlerin yapılması" çalışmanın temel amacını oluşturmaktadır. Bu amaç çerçevesinde, araştırma soruları aşağıdaki gibi belirlenmiştir:

- Kültür merkezlerinin işlevselliği nedir ve kamusal bir mekân olarak ne tür yönelimlere alan açmaktadır?

- Siyasal ideoloji(ler)in yeniden üretilmesinde, kültür merkezlerinin isimlendirilmesi ve bu merkezlerde yürütülen etkinliklere ne tür roller atfedilmektedir?

\section{Yöntem ve Materyal}

$\mathrm{Bu}$ araştırmada Creswell (2003) tarafından üçüncü yaklaşım olarak ele alınan karma (mix) araştırma yöntemi kullanılmıştır. Karma yöntem, bir yandan nitel ve nicel araştırma yöntemleri arasında ilişki kurulmasına katkı sağlarken (Onwuegbuzie ve Leech, 2004), diğer yandan araştırma sonuçlarının genellenebilmesi için de kullanılmaktadır (Johnson ve Onwuegbuzie, 2004). Söz konusu yöntemin; Üçleme, Açıklayıcı ve Keşfedici olmak üzere üç farklı uygulaması bulunurken bu çalışmada Keşfedici sıralı karma yöntemden yararlanılmıştır. Bunun anlamı; araştırmacılar önce nitel verileri keşfetmekle başladıkları çalışmada daha sonra elde ettikleri bulguları nicel araştırma boyutu ile kullanmıştır (Creswell, 2014). Diğer bir ifadeyle nicel veri ile nitel veriler çoğaltılmıştır (Creswell, 2003). Karma (mix) araştırma modeli birçok açıdan aydınlatıcı sonuçlar ve bağıntısal niteliklerin elde edilmesinde faydalı sonuçlar vermektedir. $\mathrm{Bu}$ bağlamda nicel araştırma yöntemleri bazen "ne" sorusunu cevaplayabilir ancak "neden" sorusuna ses veremez. Bu nedenle nitel yöntemler "belirli bir anlayış1 ortaya çıkarmak ve keşfetmek için farklı görme yöntemleri” kullanır (Munhall, 2007: xv). Böylelikle alan araştırmasında, tümevarımsal bir yaklaşımla temin edilen veriler, daha sonra belirlenen amaç doğrultusunda analize tabi tutulmuş ve her iki veri seti arasındaki bağıntının istatistiksel olarak anlamlılık düzeyi test edilerek, ilgili verilerin anlaşılırlı̆̆ pekiştirilmiştir. Bu bağlamda, araştırma dört aşamada tamamlanmıştır:

1. aşamada Ankara'nın merkez ilçelerinde (Altındağ, Çankaya, Etimesgut, Gölbaşı, Keçiören, Mamak, Pursaklar, Sincan ve Yenimahalle) yer alan tüm kültür merkezleri çalışmanın evreni olarak belirlenmiştir. Bu kapsamda Ankara kent merkezindeki 68 kültür merkezinin bağlı bulundukları belediye başkanlıklarının internet adresleri, il tanıtım kitapçıkları (Ankara Kalkınma Ajansı, 2017; Ankara Valiliği, 2013) ile "Google Harita" ve "Google Gezegen" uygulamaları kullanılarak tespit edilmiştir. Bu tespitler Microsoft Excel ortamında kaydedilerek bir ön değerlendirme yapılmıştır.

2. aşamada kültür merkezi idarecilerinin ve bu merkezlerden yararlanan kursiyerlerin öznel değerlendirmelerini almak için yapılandırılmış görüşme tekniği uygulanmıştır. Bu uygulamayla amaç; katılımcıların bir temaya ilişkin fikir, tutum ve düşüncelerini anlamak ve insanların deneyimledikleri yaşamsal formları ve pratikleri nasıl yorumladıklarını ele almaktır (Özgen, 2016: 158). Bu araştırmaya ilişkin saha çalışması; Ekim-Aralık 2019 tarihleri arasında yapılmıştır. Tasarlanan çalışma planı gereği; Ankara ilinin 9 merkez ilçesindeki belediye başkanlıklarına resmi yazı ile başvuruda bulunulmuş ve 
yedi ilçe belediyesinden (Gölbaşı ve Sincan ilçe belediyeleri hariç) araştırma izni alınabilmiştir. Bu nedenle saha araştırması, Gölbaşı ve Sincan dışında kalan toplam yedi merkez ilçedeki seçilen faal kültür merkezleri temel alınarak yürütülmüştür. Araştırmaya katkı sunan katılımcıların ilçelere göre dağılımı Çizelge 1'de verilmiştir:

Çizelge 1. Katılımcıların (kursiyer ve yöneticilerin) ilçelere göre dağılımı

\begin{tabular}{lcccc}
\hline İlçe & $\begin{array}{c}\text { Kursiyer/ } \\
\text { katılımc1 }\end{array}$ & $\begin{array}{c}\text { Yönetici } \\
\text { katılımc1 }\end{array}$ & $\begin{array}{c}\text { Toplam } \\
\text { katılımcı }\end{array}$ & Yüzde \\
\hline Altındağ & 10 & 2 & 12 & $15 \%$ \\
Çankaya & 11 & 3 & 14 & $17 \%$ \\
Etimesgut & 9 & 1 & 10 & $12 \%$ \\
Keçiören & 12 & 3 & 15 & $18 \%$ \\
Mamak & 12 & 2 & 14 & $17 \%$ \\
Pursaklar & 5 & 2 & 7 & $9 \%$ \\
Yenimahalle & 8 & 2 & 10 & $12 \%$ \\
Toplam & 67 & 15 & 82 & $100 \%$ \\
\hline
\end{tabular}

Yenimahalle ve Pursaklar ilçesinden birer, geriye kalan diğer beş ilçeden ise ikişer olmak üzere toplam 12 kültür merkezinde görev yapan 15 yönetici ve bu merkezleri ziyaret eden 67 katılımcı olmak üzere toplam 82 katılımcı araştırmaya dâhil edilmiştir. Araştırmaya ilişkin verilerin toplanması için her bir katılımcı için ayrı bir görüşme (cevap formu) kullanılmış ve tüm formlar sırasıyla numaralandırılmıştır. Kültür merkezleri belirli gün ve saatte ziyaret edilerek, katılımcılarla yüz yüze görüşmeler gerçekleştirilmiş̧ir. Katılımcıların görüşme formlarında belirtilen sorulara verdikleri cevaplar dikkatle okunmuş ve araştırma konusuyla ilgili olduğu belirlenen kavram ve tanımlamaların altı çizilerek, ayrı bir dosyaya aktarılmış ve kayıt altına alınmıştır. Ayrıca metin içinde görüşlerine yer verilen iki katılımcı grupla ilgili belirli kısaltmalar yapılmış, kaç numaralı yönetici (Y) veya kültür merkezindeki hizmetlerden yararlanan kursiyer/katılımc1 $(\mathrm{K})$ anlamına gelen k1saltmaların (Y1. Y2. Y3 veya $\mathrm{K} 1$. K2. K3 vs) yanı sıra, katılımcıların cinsiyetlerini belirten (Erkek/E, Kadın/K) kodlamalar, yaş ve meslekleri de kullanılmıştır. Örneğin "Y5 (K10), Mamak, K, 35, Ev hanımı" şeklinde metin içinde verilen bir referansın açılımı şöyledir: "5 nolu Yönetici (10 nolu Katılımcı), Kadın, 35 yaşında, Mamak ilçesi, Ev hanımı". Ayrıca, kültür merkezlerine yapılan ziyaretlerde yerinde gözlemler yapılmış, destekleyici materyaller toplanmış, fotoğraflar ve basılı materyallerle de çalışmaya katkı sağlanmıştır. Böylelikle kültür merkezlerinin mekânsal niteliği, sergilenen kültürel ortam ve gerçekleştirilen hizmetler üzerinden mevcut siyasal ideolojilerin ilişkiselliği irdelenmiştir.

3. aşamada içerik analizi tekniği kullanılmış ve alan çalışması sırasında elde edilen nitel veriler, derinlikli bir şekilde çözümlenmiştir. Nitel araştırmalarda çokça yararlanılan içerik analizi tekniği, ele alınan konuya ait derinlemesine ve örüntüsel bir çıkarsamadır (Özgen, 2020: 39). Patton (2014) içerik analizini, geniş kapsamlı nitel verilerin içerisindeki tutarlılıkları ve ilişkileri tespit ederek ona anlam kazandıracak seviyeye indirgenmesi ve anlamlandırılması olarak tanımlamaktadır. İçerik analizinde; katılımcıların görüşleri, gözlemleri veya herhangi bir dokümanın içeriğine ilişkin analizlerde tespit edilen kavramlar ve bu kavramlar arasındaki ilişki, anlamlı ve tutarlı bir şekilde açıklanır ve tanımlanır (Özgen, 2016:184). İçerik; sözcük, anlam, düşünce ve iletiden oluşabileceği gibi aynı zamanda her türlü resim, sembol ve temayı da içerebilir. Bu bağlamda iletişim ortamı işlevi gören her türlü görsel ya da sözlü öğe metin olarak ele alınmaktadır (Neuman, 2014: 466). İçerik analiziyle ele alınan metinler belirli kavram ve temalar bazında gruplanır ve okuyucular tarafından anlaşılabilecek şekilde sunulur (Yıldırım 
ve Şimşek, 2008). Başka bir anlatımla, bu teknik metin içerisindeki mesajlar; gönderen, mesajın kendisi ve alıcısı hakkındaki yorumların bir dizi işlem sonucunda ortaya konulmasıdır (Weber, 1989: 5). Bu bağlamda, nicel araştırmalardan farklı olarak, nitel araştırmaların amacı, nesnel bir yaklaşım ve genelleyici gerçeklikler oluşturmak değil, araştırmalardan elde edilen sonuçları anlamak ve bunları yorumlamaktır (Bal, 2016; Baş ve Akturan, 2017). Sonuç olarak, alan çalışmasıyla toplanan bulguların düzenlenerek ve yorumlanarak okuyucuya aktarılabilmesi için araştırma verilerinin çözümlenmesinde betimsel durum ve içerik analizi teknikleri kullanılmıştır (Cope, 2005: 224; Özgen, 2016:186-188). Çalışmadaki içerik analizi altı adımda yürütülmüştür:

Illk adımda her bir katılımcının formunda yer alan ve yararlanılmasına karar verilen ifadeler işaretlenmiştir. İkinci adımda; işaretlenen 810'u farklı olmak üzere toplam 1.066 ifade/ kavram alfabetik olarak listelenmiştir. Üçüncü adımda; metin içinde kullanıldığı içerik bakımından, benzerlik ve farklılıklarına göre ayrı tematik kategoriler/ boyutlar altında toplanmış ve birbirine eş ya da yakın anlamlı 193 kavram belirlenmiştir (Şekil 2 Kavram ağı). Dördüncü adımda elde edilen tüm kavramsal ifadeler ana kategoriler altında gruplandırılmış ve bu ifadelerin frekans ve yüzdelik oranları tablolar halinde oluşturulmuştur. Beşinci adımda; anket formlarındaki kullanılma bağlamı ile ilişkili olarak kavramlar 38 alt kategori ve 9 ana kategoriye ayrılımıştır. Altıncı adımda ise katılımcı özellikleri ve diğer kategorik bilgiler itibarıyla kategori ve alt kategorilerdeki kavramların tekrar etme sıklıkları bulunarak analiz edilmiştir.

4. aşamada ise içerik analizi yapılmış ve elde edilen 9 temel kategori ile katılımcıların sosyodemografik özellikleri arasında anlamlı bir bağıntı olup olmadığını test etmek amacıyla Ki-kare bağımsızlık testi kullanılmış ve istatistiksel anlamlılık seviyesi $\mathrm{P}<0,0001$ olarak kabul edilmiştir. Buna göre demografik değişkenler ile belirlenen kategoriler arasında istatistiksel olarak anlamlı farklılıkların olduğu tespit edilmiştir. Ki-kare bağımsızlık testi iki farklı nitel değişken arasında bir ilişkinin olup olmadığını anlamak için kullanılmaktadır (Bakan ve Büyükbeşe, 2004; Bircan vd., 2003; Güngör ve Bulut, 2008). Bu çalışmada da araştırma verilerinin analizinde, karma yöntem kullanılmış ve istatistiksel veriye dayalı sonuçlarla katılımcıların görüşlerine ilişkin sonuçlar karşılaştırılarak, çözümlenmiş ve konunun anlaşılırlı̆̆ pekiştirilmiştir. Ayrıca, araştırmanın güvenirliğini sağlamak amacıyla nitel araştırma deseni ve analiz teknikleri alanında uzman iki bilim insanına, kullanılan veriler, elde edilen sonuçlar ve geliştirilen yorumlar arasında kurulan ilişkilere dönük tutarlılık kontrolü yaptırılarak, araştırmanın yöntemsel işlevselliği ve uygulama süreçlerine ilişkin teyitler alınmıştır.

Bununla birlikte araştırma, bazı kısıtlılıklar ve sınırlılıklar dâhilinde yürütülmüştür. İlçe belediyelerine bağlı kültür merkezleriyle sınırlı olan araştırma, örnekleme alınan 82 katılımcıyla sınırlıdır. Katılımcıların yapılandırılmış görüşme formlarına verdikleri cevaplar, onların gerçek durumlarını yansıttığı varsayılmaktadır. Kültür merkezlerini ziyaret eden katılımcılara uygulanan yapılandırılmış görüşme formlarının gerçekleştirilme zamanı ve genel kullanıcı profilinin kompozisyonu nedeniyle kadınlara ve erkeklere aynı oranda anket uygulanamamıştır. Araştırmada, kültür merkezlerine etki eden siyasal ideolojinin, görevdeki belediye başkanını ve/veya bağlı olduğu siyasal partinin görüşü olduğu varsayılmıştır. Bununla birlikte belediyelerde kamusal mekânlara isim verme yetkisi belediye meclisine aittir ve sadece başkanın kararı ile isimler değişememektedir. Diğer 
yandan belediye meclislerinin verdiği kararlar bazı durumlarda valilik ve kaymakamlıklarca uygun görülmeyerek reddedilebilmektedir.

\section{Bulgular}

Çalışma kapsamında hem kültür merkezi yöneticilerine hem de bu merkezlerden yararlanan kursiyerlere yöneltilen ve yapılandırılmış görüşme formlarıyla temin edilen katılımcı cevapları, içerik analiziyle incelenmiş, elde edilen kavramlar anlamsal bütünlük oluşturacak şekilde kategorilendirilmiş ve ilçeler itibarıyla ne tür anlamlı farklılıklar oluşturduğu sorgulanmıştır. Analizlerde, ilçelerdeki politik yapılanma ve kültür merkezlerinin ismi ile yürütülen faaliyetler arasındaki ilişkinin anlamlı olduğu tespit edilmiş.

\subsection{Kültür Merkezlerinin Yöneticilerine İlişkin Bulgular}

Yönetici anketlerinde toplam 17 soru bulunmaktadır. Bunlardan 4'ü kültür merkezinin ismine, 2'si katılımcı anketlerine yönelik izinlere, 3'ü merkezin tanıtım araçlarına ve 8'i de kültür merkezinin özelliklerine dair açık uçlu sorulardan oluşmaktadır. Kültür merkezindeki faaliyetlere ilişkin görüş ve öneriler içerik analizi ile değerlendirilmiş ve elde edilen bulgular aşağıda verilmiştir (Çizelge 2).

Çizelge 2. Yönetici anketlerindeki kültür merkezi isimlerine ilişkin bilgilerin değerlendirilmesi

\begin{tabular}{llccc}
\hline \multicolumn{1}{c}{ Kültür Merkezi Adı } & İlçe adı & Anket sayısı & İsim değişikliği & Özel salon isimleri \\
\hline Gültepe Kadınlar Eğitim ve Kültür Merkezi & Altındağ & 1 & Yok & Yok \\
\hline Hüseyin Gazi Kültür Merkezi & Altındağ & 1 & Var $^{(1)}$ & Yok \\
\hline Çağdaş Sanatlar Merkezi & Çankaya & 2 & Teklif edildi & Var $^{(2)}$ \\
\hline Zülfü Livaneli Kültür Merkezi & Çankaya & 1 & Yok & Var $^{(3)}$ \\
\hline Korkut Ata Kültür ve Kongre Merkezi & Etimesgut & 1 & Yok & Var $^{(4)}$ \\
\hline Yunus Emre Kültür ve Spor Merkezi & Etimesgut & 1 & Yok & Yok \\
\hline Mevlana Kültür ve Spor Merkezi & Keçiören & 2 & Yok & Yok (numaratik) \\
\hline Yunus Emre Kültür Merkezi & Keçiören & 1 & Yok & Yok (numaratik) \\
\hline Necip Fazıl Kültür Merkezi & Mamak & 1 & Yok & Yok \\
\hline Necmettin Erbakan Kongre Merkezi & Mamak & 1 & Yok & Yok \\
\hline Saray Hanımevi Kültür Merkezi & Pursaklar & 2 & Var & Yok (alfabetik) \\
\hline Nazım Hikmet Kültür Merkezi & Yenimahalle & 2 & Yok & Var
\end{tabular}

Notlar: (1) 1994 yılında yerel seçimlerden sonra Uğur Mumcu Kültür Merkezi ismi değiştirilmiştir, (2) Yaşar Kemal, Gülten Akın, Abidin Dino, Füreya Konal, Osman Hamdi Bey, Eren Eyüboğlu, Andrey Gennadiyeviç, (3) Seranad, Mutluluk, vb. (Zülfi Livaneli'nin kitapları), (4)Ömer Seyfettin, Neşet Ertaş, (5) 2017'de Gülbahar Hatun Kültür Merkezi ismi değiştirilmiştir (6)Yıldız Kenter, Hikmet Çetinkaya.

Yönetici anketlerine verilen cevaplarda; iki kültür merkezinde isim değişikliği yapıldığı, birinde ise isim değişikliği önerisinin reddedildiği belirlenmiştir. 1994 yılı yerel seçimleri ile Sosyal Demokrat Halkçı Parti'den (SHP) Refah Partisi'ne (RP) geçen Altındağ Belediyesi, meclis kararı ile seçimin hemen ardından Ŭ̆ur Muтcu Kültür Merkezi’nin ismini Hüseyin Gazi Kültür Merkezi olarak değiştirmiş ve bu değişiklik nedeniyle ilçede protesto yürüyüşü gerçekleşmiştir (Cumhuriyet Gazetesi, 1994:1). Pursaklar Gülbahar Hatun Kültür Merkezi ismi ise Saray Hanımevi Kültür Merkezi olarak değiştirilmiştir. Diğer yandan, Çankaya Çağdaş Sanatlar Merkezine, bu merkezdeki bir serginin açılışında konuşma yaptığı sırada öldürülen Rus Büyükelçi Andrey Karlov isminin verilmesi önerilmiş, ancak bu öneri reddedilmiştir. Bunun yerine ismin, mevcut salonlardan birine verilmesi uygun görülmüsşür. Genel olarak, kültür merkezlerindeki salon isimlendirmeleri incelendiğinde, 7 kültür merkezinde salonlar için özel bir isimlendirme kullanılmadığı, 4'ünde ise sanatçı ya da sanat eserlerine ilişkin isimlerin tercih edildiği belirlenmiştir. 
Yönetici anketlerinde ayrıca kültür merkezinin ismi ile kültür merkezinde yürütülen faaliyetler arasındaki bağıntılar irdelenmiştir (Çizelge 3). Görüşmelerde katılımcıların verdikleri yanıtlar, ilçelerdeki belediye başkanlıklarını kazanan siyasi partiler ile birlikte değerlendirildiğinde, kültür merkezlerinin ismi ve burada yürütülen faaliyetlerin yerel yönetimlerin siyasal tercihleri ile şekillendiği görülebilmektedir. Bunun en açık örneklerinden biri, saha çalışması sırasında yapılan görüşmelerde, Etimesgut İlçesindeki Korkut Ata Kültür Merkezi isminin bizzat belediye başkanının bağlı bulunduğu siyasi partinin (Milliyetçi Hareket Partisinin) genel başkanı tarafindan verilmiş olduğunun dile getirilmesidir. Anket sorularına verilen cevaplar neticesinde oluşturulan kavramsal bağıntılar ve ortaya çıkan temsili temalar, yerel yönetimlerin siyasi parti bağlantıları ile örtüşmektedir. Ayrıca kültür merkezlerinin içinde kullanılan görsel semboller, alt salon isimlendirmeleri ve sanat eserleri de bu siyasal temsilleri güçlendirecek şekilde seçildiğini göstermektedir.

Çizelge 3. Kültür merkezi isimleri ile bu merkezlerde yürütülen faaliyetler arasındaki ilişki

\begin{tabular}{|c|c|c|c|}
\hline Kültür Merkezinin İsmi & İlçe & Kavram ve Kişisel bağıntı & Temsili tema ve kavramlar \\
\hline $\begin{array}{l}\text { Gültepe Kadınlar Eğitim ve } \\
\text { Kültür Merkezi }\end{array}$ & Altındağ & $\begin{array}{l}\text { Bedirhan Gökçe, Serdar Tuncer, dini etkinlikler, } \\
\text { tasavvuf kursları, ney eğitimi }\end{array}$ & Mütedeyyin, Muhafazakâr \\
\hline $\begin{array}{l}\text { Hüseyin Gazi Kültür } \\
\text { Merkezi }\end{array}$ & Altındağ & $\begin{array}{l}\text { Hüseyin Gazi, Kutlu doğum haftası, Mekke'nin fethi, } \\
\text { Kur'an-1 Kerim tilaveti }\end{array}$ & Milliyetçi, Muhafazakâr \\
\hline Çağdaş Sanatlar Merkezi & Çankaya & $\begin{array}{l}\text { Topluma katkı, toplumu aydınlatan, çağdaş sanatlar, } \\
\text { "cumhuriyetin temeli kültürdür" }\end{array}$ & Sosyal Demokrat \\
\hline $\begin{array}{l}\text { Zülfü Livaneli Kültür } \\
\text { Merkezi }\end{array}$ & Çankaya & Toplumsal hizmet, toplumsal gelişim ve aydınlanma & Sosyal Demokrat \\
\hline $\begin{array}{l}\text { Korkut Ata Kültür ve } \\
\text { Kongre Merkezi }\end{array}$ & Etimesgut & $\begin{array}{l}\text { Türk büyüğü, Türk kültürünün yaşatılması, kamu } \\
\text { hizmetinin yerine getirilmesi }\end{array}$ & Milliyetçi \\
\hline $\begin{array}{l}\text { Yunus Emre Kültür ve Spor } \\
\text { Merkezi }\end{array}$ & Etimesgut & $\begin{array}{l}\text { Türk kültürü, Türk düşünürleri, Türk beyleri, Türk } \\
\text { dünyasıyla kültürel bağlar }\end{array}$ & Milliyetçi \\
\hline $\begin{array}{l}\text { Mevlana Kültür ve Spor } \\
\text { Merkezi }\end{array}$ & Keçiören & $\begin{array}{l}\text { Mevlana, Yunus Emre, Abdurrahim Karakoç, Estergon } \\
\text { Kalesi, Osmanl }\end{array}$ & Milliyetçi, Muhafazakâr \\
\hline $\begin{array}{l}\text { Yunus Emre Kültür } \\
\text { Merkezi }\end{array}$ & Keçiören & $\begin{array}{l}\text { Kuran-1 Kerim eğitimi, Cemevi, Atatürkçü Düşünce } \\
\text { Derneği, Çokkültürlülük, farklılıkların temsil edilmesi }\end{array}$ & Çokkültürlülük \\
\hline Necip Fazıl Kültür Merkezi & Mamak & Necip Fazıl heykeli & Mütedeyyin, Muhafazakâr \\
\hline $\begin{array}{l}\text { Necmettin Erbakan Kongre } \\
\text { Merkezi }\end{array}$ & Mamak & Erbakan Hoca, Ömer Döngeloğlu, Nihat Hatipoğlu & Mütedeyyin \\
\hline $\begin{array}{l}\text { Saray Hanımevi Kültür } \\
\text { Merkezi }\end{array}$ & Pursaklar & $\begin{array}{l}\text { Selçuklu kaynaklı adlar, mimaride Selçuklu çizgileri, } \\
\text { Ramazan etkinlikleri, Aşure ve Zafer bayramı } \\
\text { etkinlikleri, siyasi parti aday tanıtım toplantıları }\end{array}$ & Milliyetçi, Muhafazakâr \\
\hline $\begin{array}{l}\text { Nazım Hikmet Kültür } \\
\text { Merkezi }\end{array}$ & Yenimahalle & $\begin{array}{l}\text { Nazım Hikmet Ran programları, Şiir programları, } \\
\text { farklı siyasal eğilime sahip programlar }\end{array}$ & Sosyal Demokrat \\
\hline
\end{tabular}

$\mathrm{Bu}$ analize göre; Altındağ, Mamak ve Pursaklar ilçelerinde başta mütedeyyin-muhafazakâr isimler ve buna bağlı faaliyetlere öncelik verildiği belirlenmiştir. Etimesgut İlçesinde milliyetçi isimler ve buna ilişkin faaliyetler öne çıkmaktadır. Diğer yandan, Çankaya ve Yenimahalle ilçelerinde ise daha açık ve toplumsal gelişmelere yönelik hizmetler özellikle sosyal, kültürel ve psiko-sosyal eksenli yönelimler şeklinde dikkat çekmektedir. Ayrıca daha seküler ve sosyal demokrat olarak tanımlanabilecek isim ve faaliyetler ağırlıklı şekilde ifade edilmiştir.

Bu genellemenin dışına çıkan tek ilçe Keçiören'dir. Her ne kadar bu ilçedeki kültür merkezi isimlendirmelerinin tamamı siyasal temsillerle birebir örtüşüyor olsa da kültür merkezi yöneticileri özellikle belediye başkanının kişisel yönlendirmesi ile kültür merkezlerindeki faaliyetlerde çokkültürlülüğün sağlandığı ve toplumun tüm kesimlerinin temsil edilmesi için çaba gösterildiği belirtilmiştir. Dolayısıyla merkezi otoriteden ziyade daha yerel ve farklılıkları birleştiren çokkültürcü bir siyasal hizmet temsilinin hayata geçirildiği söylenebilir. Ayrıca, yöneticilerin tamamı kültür merkezlerindeki faaliyetlerin yeterli ve halkın dikkate alınarak düzenlendiğini belirtmiştir. 
“(Kültür merkezi) vatandaş için bulunmaz bir nimet” (Y1, Altındağ, Gültepe Kadınlar Eğitim ve Kültür Merkezi).

"Vatandaşın çok fazla beklentisi yok, memnunlar. Programları belediye yapıyor, bizim programlara etki etme şansımı yok. Ama mesela siyasi içerikli, terör övücü etkinlikler düzenlenmek isterse izin vermeyiz"(Y5, Etimesgut, Korkut Ata Kültür ve Kongre Merkezi).

"Şu anda bence kullanım amacı yerinde ve talepleri karşıladığını düsünüyorum. Çünkü koşullarımızın verdiğimiz hizmete uygun olduğunu düşünüyorum” (Y16, Keçiören, Yunus Emre Kültür Merkezi).

Kültür merkezi yöneticileri ile yapılan görüşmelerde, katılımcı sayısının kısıtll1lı̆g 1 nedeniyle analizler sadece ana kategoriler üzerinden yapılmıştır (Çizelge 4). Bu bağlamda, kültür merkezleri yöneticilerinin düşünsel yönelimleri sanatsal gelişim (\%24), sosyo-kültürel gelişim (\%20) ve sosyoekonomik gelişme (\%19) kategorilerinde yüksek bir orana sahipken, bireysel gelişim (\%1), psiko-sosyal gelişim (\%4) ve sağllkll yaşam (\%4) kategorilerinde ise daha düşük orandadır.

Çizelge 4. Kültür merkezi yöneticilerinin kültür merkezlerine ilişkin kullandıkları kavramların frekans analizi (\%)

\begin{tabular}{lcccccccc}
\hline Kategori/İlçe & Altındağ & Çankaya & Etimesgut & Keçiören & Mamak & Pursaklar & Yenimahalle & Toplam \\
\hline Aile gelişimi & 17,90 & 2,90 & 16,70 & 9,70 & 4,80 & 15,00 & 8,70 & 9,42 \\
\hline Bireysel gelişim & 7,10 & 0,00 & 0,00 & 0,00 & 0,00 & 0,00 & 0,00 & 1,05 \\
\hline Eğitim ve bilgilenme & 10,70 & 5,70 & 8,30 & 16,10 & 11,90 & 15,00 & 8,70 & 10,99 \\
\hline Psiko-sosyal gelişme & 3,60 & 0,00 & 16,70 & 0,00 & 9,50 & 5,00 & 0,00 & 4,19 \\
\hline Sağliklı yaşam & 10,70 & 0,00 & 0,00 & 9,70 & 0,00 & 10,00 & 0,00 & 4,19 \\
\hline Sanatsal gelişme & 10,70 & 57,10 & 33,30 & 12,90 & 11,90 & 0,00 & 43,50 \\
\hline Sosyo-ekonomik gelişme & 21,40 & 5,70 & 8,30 & 9,70 & 35,70 & 45,00 & 4,30 & 19,00 \\
\hline Sosyo-kültürel gelişme & 10,70 & 20,00 & 16,70 & 38,70 & 16,70 & 5,00 & 26,10 & 20,00 \\
\hline Sosyo-politik & 7,10 & 8,60 & 0,00 & 3,20 & 9,50 & 5,00 & 8,70 & 7,00 \\
\hline
\end{tabular}

İlçeler bazında verilerin genel dağılımı incelendiğinde; aile gelişsimi, bireysel gelişim ve sağglkkl yaşam kategorilerinde Altındağ ilçesindeki yöneticilerin kullandıkları kavramların yüksek frekans oranına sahip oldukları dikkat çekmektedir. Diğer bir ifadeyle bu kategorilere ilişkin frekansların yüksek olması, ilgili yöneticilerin düşünsel yönelimlerini de kısmen görünür kılmaktadır.

"Farklı kültürleri gösterip hissettirebilecek alanların yaplması ve insanlara sunulması gerekir. Çünkü kültür ve sanat denilince akla kültürel faaliyetler, görseli olabilecek yörelere ait yerleşme şekilleri vb. kültürlere ait farkl yaşam biçimleri gelmektedir. Lakin genel duruma göre; kültür merkezlerinin genelde vatandaşlara sunulan kurslarla sinırl olduğu görülmektedir” (Y14, Keçiören, Mevlana Kültür ve Spor Merkezi).

Aynı şekilde sanatsal gelişme kategorisinde Çankaya, psiko-sosyal gelişme kategorisinde Etimesgut, eğitim ve bilgilenme ile sosyo-kültürel gelişme kategorilerinde Keçiören, sosyo-ekonomik gelişme ve sosyo-politik kategorilerinde ise Mamak ilçesindeki kültür merkezi yöneticilerin kullandıkları kavramların en yüksek frekans oranına sahip oldukları belirlenmiştir.

3.2. Kültür Merkezinden Yararlanan Kursiyerlerin/Katılımcıların Görüşlerine İlişkin Bulgular

Her ne kadar siyasal isim tercihleri ve kültür merkezi yöneticilerinin yaklaşımları belirli bir yönelim gösterse de, bu merkezlerdeki etkinliklerden yararlanan katılımcıların kültür merkezlerindeki hangi faaliyetlerden yararlandığı, ne tür etkinlikler önerdiği ve bu tercihlerin ne derece etkili olduğunun anlaşılması açısından önemlidir. Bu çerçevede kültür merkezinden yararlanan katılımcılarla (n:67) yapılan görüşmeler içerik analiziyle çözümlenerek Çizelge 5 'te belirtilmiştir. 
Buna göre katılımcıların çeşitli gerekçelerle yararlandıkları veya eğitim aldıkları kültür merkezleriyle ilgili düşüncelerini özetleyen kavramsal ifadeler, 9 kategori ve 38 alt kategoriden oluşmaktadır. Bu analizler, aynı zamanda kültür merkezlerine yönelik düşüncelerin kavramsal özetini temsil etmektedir. Katılımcıların kültür merkezlerine ilişkin görüşleri incelendiğinde, toplam oranlar bazında en yüksek oran \%21,6 ile sanatsal gelişim, ikinci sırada sosyo-kültürel gelişme (\%15) ve üçüncü sırada ise sosyo-ekonomik gelişme (\%13) olarak sıralanmaktadır. Buna karşın en az frekans oranına sahip temel kategoriler ise sırasıyla; sağllkl yaşam $(\% 5,3)$, bireysel gelişme $(\% 7,4)$ ve aile gelişimi $(\% 7,7)$ kategorileridir. Diğer bir ifadeyle, katılımcıların önceliği sanatsal gelişim, en az yönelim gösterdikleri alan ise sağglklı yaşama ilişkin yaygın eğitim ve öğretim uygulamalan olduğu belirlenmiştir.

Alt kategoriler bazında, en yüksek kavramsal ifade sayısına sahip ilk beş kategori sırasıyla; sahne sanatları $(\% 7,7)$, meslek edinme $(\% 6,2)$, müzik ve dans $(\% 5,7)$, kültürel gelişim $(\% 5,5)$ ve çocuk $(\% 4,8)$ şeklinde sıralanmaktadır. Buna karşın en düşük frekans oranına sahip kavramsal ifadeler ise, sirasıyla; el sanatları $(\% 0,4)$, yenilik/ yaratıcılı $(\% 0,5)$, farkindalık $(\% 0,6)$, aidiyet ve kimlik $(\% 0,8)$ ve kadın $(\% 0,9)$ olarak belirlenmiştir (Çizelge 5).

İlçeler itibariyle kursiyerlerin görüşleri değerlendirildiğinde, aile gelişimi kategorisinde en yüksek frekans oranına sahip kavramlar sırasıyla Altındağ $(\% 16,4)$, Pursaklar $(\% 10,8)$ ve Etimesgut $(\% 10,3)$ ilçesindeki katılımcılar tarafından ifade edildiği belirlenmiştir.

\footnotetext{
"Kültür merkezini ziyaret etmeye başladlktan sonra insanlarla ve ailemle olan etkileşimim gayet olumlu yönde gelişti ve iyi bir hal aldı" (K9, Alttndă̆, K, 50, Temizlik personeli).

"Buraya çocuk gelişimi kursuna geliyorum. Kültür merkezinde aile ve çocuk eğitimi, özellikle de evde çocuk bakımı ile ilgili faaliyetler olursa daha iyi olur" (K38, Pursaklar, K, 20, Öğrenci)

"Çocuğumun ders kursu için geliyorum. Çocuklara ders ve müzik kurslarl verilmesini öneriyorum. Müzik aleti ögrrenmek çok güzel bir şey.” (K62, Etimesgut, E, 42, Jandarma personeli)
}

Altındağ ilçesindeki katılımcılar aile gelişimi kategorisi altındaki aile ve çocuk alt kategorilerinde de ilk sırada yer almakta, Genç alt kategorisinde ise Pursaklar ilçesi ilk sırada yer almaktadır. Çankaya $(\% 0,7)$ ve Yenimahalle $(\% 3,8)$ ilçeleri ise bu kategorinin en düşük frekans oranına sahip ilçeleri olarak görülmektedir. Bireysel gelişme kategorisinde, Etimesgut ve Pursaklar hariç, ilçelerin kavram kullanma sıklığı birbirine yakındır. Keçiören ilçesi hem bireysel gelişme $(\% 10,8)$ kategorisinde hem de bilişsel gelişme $(\% 7,4)$ ve disiplinli yaşam $(\% 2,7)$ alt kategorilerinde en yüksek frekans oranına sahip kavramların ifade edildiği ilçe olarak tespit edilmiştir. En düşük frekans oranı ise Pursaklar $(\% 2,7)$ ilçesine aittir. Yenimahalle ilçesinde konfor, Çankaya ilçesinde ise yenilik/yaratıcılık alt kategorileri daha yüksek frekansa sahip kavramlar olarak öne çıkmaktadır. Eğitim ve bilgilenme kategorisinde Pursaklar ve Keçiören ilçelerindeki katılımcılar daha yüksek frekans oranına (\%14,9 ve \%12,2) sahip kavramlar kullandıkları, buna karşın Mamak ilçesindeki merkezleri ziyaret eden katılımcıların kullandıkları kavramlar ise en düşük frekans oranına $(\% 4,8)$ sahip oldukları belirlenmiştir. Ĕgitim etkinliği ve ögrenme alt kategorilerinde de daha yüksek frekans oranlarına sahip ilçeler; Keçiören ve Pursaklar olduğu görülmektedir.

Psiko-sosyal gelişme kategorisine ilişkin ifade edilen kavramların en yüksek frekans oranı $(\% 16,2)$ Pursaklar, en düşük frekans oranına sahip ilçe ise Çankaya $(\% 3,3)$ olarak belirlenmiştir. 
Arkadaşlık alt kategorisinde Keçiören, farkındalık alt kategorisinde Pursaklar, iletişim ve iyi olma hali alt kategorilerinde Altındağ ve sosyal gelişme alt kategorisinde ise Etimesgut en yüksek frekans oranına sahip ilçeler olmuştur. Sağlıkl yaşam kategorisinin $(\% 10,4)$ yanı sıra, sağlık ve beslenme $(\% 7,1)$ alt kategorisinde Altındağ ilçesi öne çıkmaktadır. Spor alt kategorisinde ise Keçiören ilçesi en yüksek frekans oranına sahip kavramsal ifadelerin kullanıldığı ilçe olmuştur. Çankaya (\%2) ve Yenimahalle $(\% 1,9)$ ise bu kategoride en düşük frekans oranına sahip ilçeler olarak görülmektedir.

Çizelge 5. Kursiyerlerin/katılımcıların kültür merkezine ilişkin görüşlerinin frekans analizi

\begin{tabular}{|c|c|c|c|c|c|c|c|c|c|}
\hline \multirow{2}{*}{ Kategori } & \multirow{2}{*}{ Alt kategori } & Altındağ & Çankaya & Etimesgut & Keçiören & Mamak & Pursaklar & Y.mahalle & Toplam \\
\hline & & 10 & 11 & 9 & 12 & 12 & 5 & 8 & $\mathrm{n}=67$ \\
\hline \multirow{4}{*}{$\begin{array}{l}\text { Aile } \\
\text { gelişimi (\%) }\end{array}$} & Aile & 3,8 & 0,0 & 2,9 & 0,7 & 1,7 & 1,4 & 0,0 & 1,7 \\
\hline & Çocuk & 10,4 & 0,0 & 5,2 & 3,4 & 4,4 & 6,8 & 2,8 & 4,8 \\
\hline & Genç & 2,2 & 0,7 & 2,3 & 0,0 & 0,4 & 2,7 & 0,9 & 1,2 \\
\hline & Ara toplam $(\%)$ & 16,4 & 0,7 & 10,3 & 4,1 & 6,6 & 10,8 & 3,8 & 7,7 \\
\hline \multirow{5}{*}{$\begin{array}{l}\text { Bireysel } \\
\text { gelişme (\%) }\end{array}$} & Bilişsel gelişme & 4,9 & 3,9 & 2,3 & 7,4 & 5,7 & 1,4 & 3,8 & 4,5 \\
\hline & Disiplinli yaşam & 1,1 & 0,7 & 0,0 & 2,7 & 0,4 & 0,0 & 0,9 & 0,8 \\
\hline & Konfor & 1,1 & 0,0 & 0,6 & 0,7 & 3,1 & 1,4 & 4,7 & 1,6 \\
\hline & Yenilik/yaratıcılık & 0,0 & 2,6 & 0,0 & 0,0 & 0,4 & 0,0 & 0,0 & 0,5 \\
\hline & Ara toplam (\%) & 7,1 & 7,2 & 2,9 & 10,8 & 9,6 & 2,7 & 9,4 & 7,4 \\
\hline \multirow{4}{*}{$\begin{array}{l}\text { Eğitim- } \\
\text { bilgilenme } \\
(\%) \\
\end{array}$} & Eğitim etkinliği & 4,4 & 2,6 & 2,9 & 5,4 & 2,6 & 4,1 & 4,7 & 3,7 \\
\hline & Öğrenme & 3,8 & 3,9 & 4,0 & 6,8 & 0,9 & 6,8 & 1,9 & 3,7 \\
\hline & Okuma-yazma becerisi. & 1,1 & 1,3 & 1,1 & 0,0 & 1,3 & 4,1 & 0,0 & 1,1 \\
\hline & Ara toplam $(\%)$ & 9,3 & 7,9 & 8,0 & 12,2 & 4,8 & 14,9 & 6,6 & 8,4 \\
\hline \multirow{6}{*}{$\begin{array}{l}\text { Psiko-sosyal } \\
\text { gelişme }(\%)\end{array}$} & Arkadaşlık & 3,8 & 0,0 & 4,0 & 8,1 & 2,2 & 5,4 & 4,7 & 3,8 \\
\hline & Farkındalık & 0,5 & 0,0 & 0,6 & 0,0 & 0,9 & 1,4 & 0,9 & 0,6 \\
\hline & İletişim & 3,3 & 0,0 & 0,0 & 1,4 & 0,0 & 2,7 & 1,9 & 1,1 \\
\hline & İyi olma hali & 5,5 & 2,6 & 5,2 & 2,7 & 3,9 & 5,4 & 2,8 & 4,0 \\
\hline & Sosyal gelişme & 0,0 & 0,7 & 2,3 & 0,7 & 1,7 & 1,4 & 0,0 & 1,0 \\
\hline & Ara toplam $(\%)$ & 13,1 & 3,3 & 12,1 & 12,8 & 8,7 & 16,2 & 10,4 & 10,5 \\
\hline \multirow{3}{*}{$\begin{array}{l}\text { Sağlıklı } \\
\text { yaşam (\%) }\end{array}$} & Sağlık ve beslenme & 7,1 & 0,7 & 1,1 & 3,4 & 1,7 & 1,4 & 0,9 & 2,5 \\
\hline & Spor & 3,3 & 1,3 & 2,9 & 5,4 & 2,2 & 2,7 & 0,9 & 2,7 \\
\hline & Ara toplam $(\%)$ & 10,4 & 2,0 & 4,0 & 8,8 & 3,9 & 4,1 & 1,9 & 5,3 \\
\hline \multirow{8}{*}{$\begin{array}{l}\text { Sanatsal } \\
\text { gelişim } \\
(\%)\end{array}$} & El sanatları & 1,6 & 0,0 & 0,0 & 0,0 & 0,4 & 0,0 & 0,0 & 0,4 \\
\hline & İslami sanatlar & 1,6 & 0,0 & 4,0 & 2,7 & 0,0 & 0,0 & 0,0 & 1,3 \\
\hline & Müzik ve dans & 0,5 & 8,6 & 6,3 & 6,1 & 5,2 & 5,4 & 10,4 & 5,7 \\
\hline & Resim, heykel, foto & 0,5 & 8,6 & 2,3 & 2,0 & 0,4 & 1,4 & 0,9 & 2,3 \\
\hline & Sahne sanatları & 6,6 & 8,6 & 6,9 & 3,4 & 7,9 & 5,4 & 17,0 & 7,7 \\
\hline & Sanatsal aktiviteler & 0,0 & 13,8 & 0,6 & 0,0 & 3,5 & 1,4 & 2,8 & 3,2 \\
\hline & Seramik ve cam & 0,0 & 2,6 & 1,7 & 1,4 & 0,9 & 0,0 & 0,0 & 1,0 \\
\hline & Ara toplam $(\%)$ & 10,9 & 42,1 & 21,8 & 15,5 & 18,3 & 13,5 & 31,1 & 21,6 \\
\hline \multirow{5}{*}{$\begin{array}{l}\text { Sosyo- } \\
\text { ekonomik } \\
\text { gelişme (\%) }\end{array}$} & Dil & 0,5 & 0,7 & 5,7 & 2,7 & 3,5 & 6,8 & 1,9 & 2,9 \\
\hline & Ekonomik kazanım & 2,7 & 0,0 & 0,6 & 1,4 & 1,7 & 1,4 & 0,0 & 1,2 \\
\hline & İstihdam & 1,6 & 0,0 & 2,3 & 3,4 & 5,2 & 6,8 & 0,0 & 2,7 \\
\hline & Meslek edinme & 11,5 & 1,3 & 4,0 & 8,8 & 7,9 & 5,4 & 0,9 & 6,2 \\
\hline & Ara toplam $(\%)$ & 16,4 & 2,0 & 12,6 & 16,2 & 18,3 & 20,3 & 2,8 & 13,0 \\
\hline \multirow{5}{*}{$\begin{array}{l}\text { Sosyo- } \\
\text { kültürel } \\
\text { gelişme (\%) }\end{array}$} & Çokkültürlülük & 0,0 & 0,7 & 1,1 & 0,7 & 5,2 & 2,7 & 0,9 & 1,8 \\
\hline & Kültürel faaliyetler & 1,1 & 11,2 & 2,9 & 0,7 & 2,2 & 1,4 & 4,7 & 3,4 \\
\hline & Kültürel gelişiim & 2,2 & 6,6 & 6,3 & 9,5 & 4,4 & 4,1 & 6,6 & 5,5 \\
\hline & Sosyal etkinlik & 3,8 & 3,3 & 3,4 & 2,0 & 5,7 & 4,1 & 8,5 & 4,3 \\
\hline & Ara toplam (\%) & 7,1 & 21,7 & 13,8 & 12,8 & 17,5 & 12,2 & 20,8 & 15,0 \\
\hline \multirow{7}{*}{$\begin{array}{l}\text { Sosyo- } \\
\text { politik (\%) }\end{array}$} & Aidiyet ve kimlik & 0,0 & 0,7 & 3,4 & 0,0 & 0,4 & 0,0 & 0,0 & 0,8 \\
\hline & Dini konular & 3,8 & 0,0 & 0,6 & 4,1 & 3,9 & 5,4 & 0,0 & 2,5 \\
\hline & Kadın & 0,5 & 0,0 & 0,6 & 0,0 & 2,6 & 0,0 & 1,9 & 0,9 \\
\hline & Politika & 1,6 & 5,9 & 3,4 & 0,0 & 1,3 & 0,0 & 5,7 & 2,5 \\
\hline & Tarih & 1,1 & 4,6 & 4,0 & 2,0 & 1,7 & 0,0 & 2,8 & 2,4 \\
\hline & Toplumsal değerler & 2,2 & 2,0 & 2,3 & 0,7 & 2,2 & 0,0 & 2,8 & 1,9 \\
\hline & Ara toplam (\%) & 9,3 & 13,2 & 14,4 & 6,8 & 12,2 & 5,4 & 13,2 & 11,1 \\
\hline
\end{tabular}

Sanatsal gelişim kategorisinde Çankaya $(\% 42,1)$ ve Yenimahalle $(\% 31,1)$ ilçelerindeki katılımcıların kültür merkezleriyle ilgili diğer ilçelerden çok daha yüksek frekans oranına sahip kavramlar kullandıkları belirlenmiştir. Buna karşın Pursaklar $(\% 13,5)$ ve Keçiören $(\% 15,5)$ ise bu 
kategoride en düşük frekans oranına sahip kavramsal ifadelerin kullanıldığı ilçeler olmuştur. Alt kategoriler itibariyle Altındağ el sanatlarında, Etimesgut İslami sanatlarda, Yenimahalle müzik-dans ve sahne sanatlarında, Çankaya ise müzik ve dans, heykel ve fotoğrafçılık, sahne sanatları, sanatsal aktiviteler, seramik ve cam alt boyutlarında en yüksek frekans oranına sahip ilçe olarak belirlenmiştir.

"Sanatı sevdirecek ve sanatın yapılmasını teşvik edecek detaylı çalışmalar ve uzmanlarının sunduğu bildiriler olmasın isterim" (K11, Çankaya, 25, Müzik öğretmeni).

Sosyo-ekonomik gelişme kategorisinde Pursaklar $(\% 20,3)$ ve Mamak $(\% 18,3)$ ilçelerindeki katılımcıların kullandıkları kavramların yüksek frekans oranına sahip oldukları belirlenmiştir. Çankaya $(\% 2)$ ve Yenimahalle $(\% 2,8)$ ise bu kategoride diğer tüm ilçelerden çok daha düşük frekans oranına sahip kavramların ifade edildiği ilçeler olmuştur. Altındağ ilçesinde ekonomik kazanım $(\% 2,7)$ ve meslek edinme $(\% 11,5)$ Pursaklar ilçesinde ise dil $(\% 6,8)$ ve istihdam $(\% 6,8)$ alt kategorileri öne çıkmıştır. Bu çerçevede katılımcılar aşağıdaki ifadeleri ortaya koymuştur:

"Belediye malzeme sağllyor. Hanımlar yaptıkları ürünleri belediye aracılı̆̆gyla satarak, para kazanabilir" (K5, Alttndăg, K, 53, Ev hanımı).

"Burada öğrendiklerimizi evde yapıp satıyoruz. Ekonomik açıdan katkı kazanç sağlıyoruz. Ayrıca kendimi geliştiriyorum” (K24, Mamak, K, “yaş sorusu cevaplanmamış”, Ev hanımı)

"İngilizce kursu açılırsa çok iyi olur. Diğer kursların açılmasını isterim. Arapça konusunda da kurslar devam etmeli." (K40, Pursaklar, K, 36, Ev hanımı).

"Kendimi daha fazla geliştirdiğim, sertifika almamı ve ileride işe girmemi săglayacak kurslar istiyorum. (K20, Pursaklar, K, 20, Öğrenci).

Çankaya ve Yenimahalle ilçelerindeki kültür merkezlerinde daha çok sanatsal ve kültürel etkinlikler, Pursaklar ve Mamak ilçelerinde ise sosyo-ekonomik etkinliklerin öne çıktığı, katılımcıların ifadeleriyle teyit edilmiştir. Sosyo-kültürel gelişme kategorisinde, yüksek frekans oranına sahip kavramlar Çankaya $(\% 21,7)$ ve Yenimahalle'de $(\% 20,8)$, en düşük frekans oranına sahip kavramlar ise Altındağ ilçesinde ikamet eden katılımcılar tarafından ifade edilmiştir. Alt kategori bazında da ilçelere göre farklı frekans oranları tespit edilmiştir. Mamak'ta $(\% 5,2)$ çokkültürlülük, Çankaya'da $(\% 11,2)$ kültürel faaliyetler, Keçiören'de $(\% 9,5)$ kültürel gelişim ve Yenimahalle $(\% 8,5)$ ilçesinde ise Sosyal etkinlik alt kategorileri ilk sırada yer alan kavramsal ifadeler olmuştur.

Sosyo-politik kategorisinde, katılımcıların kültür merkezleriyle ilgili görüşlerini yansıtan ifadelerin en yüksek frekans oranına sahip olduğu ilçeler Etimesgut $(\% 14,4)$ ve Yenimahalle $(\% 13,2)$, buna karşın en düşük frekans oranına sahip ifadelerin dile getirildiği ilçe ise Pursaklar (\%5,4) olmuştur. Alt kategorileri itibariyle; politika ve tarih alanıyla ilgili Çankaya, aidiyet ve kimlikte Etimesgut, Kadın konusuyla ilgili Mamak, dini konularda Pursaklar ve toplumsal değerler alanında ise Yenimahalle ilçesindeki katılımcıların kullandığı ifadelerin daha yüksek frekans oranına sahip kavramlar oldukları belirlenmiştir.

"Yarınlarımız için, bilgilendirme amacıyla yapılması gereken dini hizmetler ve maneviyat konusundaki etkinliklerin yapılması bizim için çok daha iyi olur" (K36, Pursaklar, K, 55, Ev hanımı).

Metropol ilçeler bazında yapılan analizler genel olarak incelendiğinde, Altındağ ve Pursaklar ilçeleri ile Yenimahalle ve Çankaya ilçelerinin farklı kategorilerde yer aldıkları ve her iki kategoride yer 
alan iki ilçenin de birbirilerine çok yakın kavram kullanma frekanslarına sahip oldukları görülmektedir. Diğer yandan katılımcıların sosyo-ekonomik gelişmişlik düzeylerine göre kültür merkezlerinden yararlanma durumu ve beklentilerinin de ciddi oranda farklılaştığı anlaşılmaktadır.

"Ücretli kursların ücretlerinin düşmesini ya da ücretsiz hale getirilmesini isterim” (K19, Keçiören, K, 49, Ev hanımi).

"Spor salonu ücretsiz olabilir. Ev hanımları için ücretsiz zumba kursu açılabilir.” (K23, Keçiören, K, 33, Ev hanımi).

"Resmi daha sonra eğitimsel olarak da kullanabilirim. Kendimi istihdam etmek için de kullanabilirim, çünkü bu tarz kültür merkezleri, doğru kullanıldı̆̆g takdirde, insanların en güzel istihdam edilebileceği alanlardan bir yer olabiliyor. Çünkü psikologlara filan gitmekten ziyade kendi istediğimiz birçok alanda çeşitli etkinlikleri değerlendirerek, hem sosyal ve kültürel hem ruhen çok iyi geldiğini (düşünüyorum), (bu nedenle) ve bu tür kültür merkezlerinin artırlması gerektiğini düşüyorum." (K65, Etimesgut, K, 55, Emekli).

Gelir seviyesi yüksek olan ilçelerde kültür merkezleri; sanatsal ve kültürel faaliyetler için kullanılırken, gelir seviyesi düşük ilçelerde ise kültür merkezleri; iki temel işlev görmektedir: Bunlardan ilki doğrudan ya da dolaylı bir şekilde, gelir artırıcı faaliyetlerin (eğitim, meslek kursları, sertifika programı, geçimlik el sanatları ve becerileri gibi) sağlanmasıdır. İkincisi ise, yüksek ücretli sosyal aktivitelerin (spor, kişisel gelişim kursları, aile gelişimi ve etkinlikleri) kültür merkezlerinde düşük ücretli ya da ücretsiz olarak temin edilebilmesidir.

Çizelge 6. Kültür merkezlerini tanımlayan kategoriler ile ilçeler değişkeni arasındaki bağıntının Ki-kare analizi.

\begin{tabular}{|c|c|c|c|c|c|c|c|c|}
\hline Kategoriler/İlçeler & $\begin{array}{l}\text { Altındağ } \\
(f ; \%)\end{array}$ & $\begin{array}{c}\text { Çankaya } \\
(f ; \%)\end{array}$ & $\begin{array}{c}\text { Etimesgut } \\
(f ; \%)\end{array}$ & $\begin{array}{l}\text { Keçiören } \\
(f ; \%)\end{array}$ & $\begin{array}{r}\text { Mamak } \\
(f ; \%)\end{array}$ & $\begin{array}{l}\text { Pursaklar } \\
(f ; \%)\end{array}$ & $\begin{array}{c}\text { Y.Mahalle } \\
(f ; \%)\end{array}$ & $\begin{array}{c}\text { Toplam } \\
(f ; \%)\end{array}$ \\
\hline \multirow{2}{*}{ Aile gelişimi } & 30 & 1 & 18 & 6 & 15 & 8 & 4 & 82 \\
\hline & $16,4 \%$ & $0,7 \%$ & $10,3 \%$ & $4,1 \%$ & $6,6 \%$ & $10,8 \%$ & $3,8 \%$ & $7,7 \%$ \\
\hline \multirow{2}{*}{ Bireysel gelişme } & 13 & 11 & 5 & 16 & 22 & 2 & 10 & 79 \\
\hline & $7,1 \%$ & $7,2 \%$ & $2,9 \%$ & $10,8 \%$ & $9,6 \%$ & $2,7 \%$ & $9,4 \%$ & $7,4 \%$ \\
\hline \multirow{2}{*}{ Eğitim-bilgilenme } & 17 & 12 & 14 & 18 & 11 & 11 & 7 & 90 \\
\hline & $9,3 \%$ & $7,9 \%$ & $8,0 \%$ & $12,2 \%$ & $4,8 \%$ & $14,9 \%$ & $6,6 \%$ & $8,4 \%$ \\
\hline \multirow{2}{*}{ Psiko-sosyal gelişme } & 24 & 5 & 21 & 19 & 20 & 12 & 11 & 112 \\
\hline & $13,1 \%$ & $3,3 \%$ & $12,1 \%$ & $12,8 \%$ & $8,7 \%$ & $16,2 \%$ & $10,4 \%$ & $10,5 \%$ \\
\hline \multirow{2}{*}{ Sağlıklı yaşam } & 19 & 3 & 7 & 13 & 9 & 3 & 2 & 56 \\
\hline & $10,4 \%$ & $2,0 \%$ & $4,0 \%$ & $8,8 \%$ & $3,9 \%$ & $4,1 \%$ & $1,9 \%$ & $5,3 \%$ \\
\hline \multirow{2}{*}{ Sanatsal gelişme } & 20 & 64 & 38 & 23 & 42 & 10 & 33 & 230 \\
\hline & $10,9 \%$ & $42,1 \%$ & $21,8 \%$ & $15,5 \%$ & $18,3 \%$ & $13,5 \%$ & $31,1 \%$ & $21,6 \%$ \\
\hline \multirow{2}{*}{$\begin{array}{l}\text { Sosyo-ekonomik } \\
\text { geliş. }\end{array}$} & 30 & 3 & 22 & 24 & 42 & 15 & 3 & 139 \\
\hline & $16,4 \%$ & $2,0 \%$ & $12,6 \%$ & $16,2 \%$ & $18,3 \%$ & $20,3 \%$ & $2,8 \%$ & $13,0 \%$ \\
\hline \multirow{2}{*}{$\begin{array}{l}\text { Sosyo-kültürel } \\
\text { gelişme }\end{array}$} & 13 & 33 & 24 & 19 & 40 & 9 & 22 & 160 \\
\hline & $7,1 \%$ & $21,7 \%$ & $13,8 \%$ & $12,8 \%$ & $17,5 \%$ & $12,2 \%$ & $20,8 \%$ & $15,0 \%$ \\
\hline \multirow{2}{*}{ Sosyo-politik } & 17 & 20 & 25 & 10 & 28 & 4 & 14 & 118 \\
\hline & $9,3 \%$ & $13,2 \%$ & $14,4 \%$ & $6,8 \%$ & $12,2 \%$ & $5,4 \%$ & $13,2 \%$ & $11,1 \%$ \\
\hline \multirow{2}{*}{ Toplam } & 183 & 152 & 174 & 148 & 229 & 74 & 106 & 1066 \\
\hline & $100 \%$ & $100 \%$ & $100 \%$ & $100 \%$ & $100 \%$ & $100 \%$ & $100 \%$ & $100 \%$ \\
\hline
\end{tabular}

Chi-Square $\left(\chi^{2}\right)=197,210^{\mathrm{a}} ; \mathrm{df} / \mathrm{sd}=48 ; \mathrm{p}<, 0001$

${ }^{a}$ Beklenen frekans değeri 5 'ten küçük olan sadece bir hücre $(\% 1,6)$ vardır.

Çizelge 6'da yer alan Ki-kare analiz sonuçları değerlendirildiğinde, aile ve sağlık kategorilerinde Altındağ; birey kategorisinde Keçiören; eğitim, psiko-sosyal ve sosyo-ekonomik kategorilerinde Pursaklar ilçesinde ikamet eden katılımcıların oransal yüksekliği dikkat çekmektedir. Benzer şekilde sanatsal ve sosyo-kültürel kategorilerde Çankaya ve Yenimahalle; sosyo-politik 
kategoride ise Etimesgut ilçesinin yanı sıra Çankaya ve Yenimahalle ilçelerindeki katılımcıların da yüksek oranda kültür merkezlerini ziyaret ettikleri ve bu kategorilere ilişkin alt tematik faaliyetlerden yararlandıkları görülmektedir. Buna karşın, Çankaya ve Yenimahalle ilçelerindeki kültür merkezlerini ziyaret eden katılımcıların; aile, sağllk, sosyo-ekonomik ve hatta psiko-sosyal kategorileriyle ilgili olarak, kültür merkezlerine yönelik ilgi ve ziyaretlerinin oldukça sinırlı olduğu görülmektedir. Etimesgut ve Pursaklar ilçelerindeki kültür merkezlerinden yararlanan katılımcıların bireysel gelişme ve sağllklı yaşam, Mamak ilçesindeki katılımcıların ise eğitim-bilgilenme ve sağlıklı yaşam kategorileriyle ilgili kavramsal ifadelerinin düşük frekans oranına sahip olduğu belirlenmiştir.

Ezcümle, Çankaya ve Yenimahalle ilçelerindeki katılımcıların kültür merkezlerini ziyaret etmeleri çoğunlukla sosyo-kültürel, sanatsal ve sosyo-politik kategorilerle ilgili kazanımlara yönelik olduğu görülmektedir. Altındağ, Keçiören, Mamak ve Pursaklar ilçelerindeki kültür merkezlerini ziyaret eden katılımcıların da çoğunlukla sosyo-ekonomik kategoriyle ilgili kazanımları amaçladıkları tespit edilmiştir. Buna karşın Pursaklar, Altındağ, Keçiören ve Etimesgut ilçelerindeki katılımcıların ise psikososyal kategorisindeki kazanımlara ulaşmak amacıyla ilgili kültür merkezlerinden yararlandıkları belirlenmiştir.

Temel kategoriler itibariyle yapılan değerlendirmelerin yanında alt kategoriler de dikkate alındığında ilçeler bazında benzerlikler ve farklılıklar daha yakından gözlenebilmektedir. Çizelge 7'de ana kategoriler altında, katılımcıların en çok atıfta bulundukları alt kategorilerin ilçelere göre dağılımı yer almaktadır. Buna göre aile gelişimi kategorisinde Çankaya ilçesindeki kültür merkezlerini ziyaret eden katılımcılar için genç alt kategorisine ilişkin vurgular öne çıkarken, diğer ilçelerdeki kültür merkezlerini ziyaret eden katılımcılarda ise çocuk alt kategorisinin öne çıktığı görülmektedir. Bireysel gelişme alt kategorisi Yenimahalle ilçesi hariç tüm ilçelerde baskın yönelim olarak öne çıkarken, bu ilçede konfor alt kategorisi öne çıkmıştır. eğitim ve bilgilenme kategorisinde ise Altındağ, Mamak ve Yenimahalle'de eğitim alt kategorisindeki kavramlara daha fazla yer verilirken, diğer ilçelerde ise Öğrenme alt kategorisine ait kavramların daha fazla kullanıldığı belirlenmiştir.

Psiko-sosyal gelişme kategorisinde Keçiören ve Yenimahalle ilçelerinde arkadaşlık alt kategorisindeki kavramlar öne çıkarken diğer tüm ilçelerde iyi olma hali alt kategorisi ilk sırada yer almaktadır. Sağlıklı yaşam kategorisinde Altındağ ilçesinde sağllk ve beslenme alt kategorisine ilişkin kavramlar ağırlık kazanırken, diğer ilçelerde ise Spor alt kategorisi ilk sırada yer almaktadır. Sanatsal gelişme kategorisinde sahne sanatları alt kategorisi öne çıkarken, Çankaya'da sanatsal aktiviteler ve Keçiören'de müzik ve dans alt kategorileri en sık tekrar edilen kavramlar olmuştur. Sosyo-ekonomik gelişme kategorisinde meslek edinme alt kategorisindeki kavramlar ağırlıklıken; Etimesgut, Pursaklar ve Yenimahalle ilçelerinde dil alt kategorisindeki kavramların öncelik kazandığı görülmektedir.

İlçeler arasında en çok farklılaşan sosyo-kültürel gelişme kategorisi olmuştur. Bu kategoride Altındağ, Mamak, Pursaklar ve Yenimahalle ilçelerinde sosyal etkinlik, Etimesgut, Keçiören ve Pursaklar ilçesinde kültürel gelişim alt kategorilerindeki kavramlar daha sık ifade edilirken, Çankaya ilçesinde kültürel faaliyetler alt kategorisi öne çıkmıştır. Son olarak sosyo-politik kategorisinde dini konular alt kategorisi öne çıarken, Çankaya ve Yenimahalle ilçelerinde politika alt kategorisi ve Etimesgut ilçesinde ise tarih alt kategorisindeki kavramlar daha fazla dile getirilmiştir. 
İlçeler özelinde genel sonuçlar karşılaştırıldığında en büyük farklılı̆̆ın Yenimahalle ve Çankaya ilçelerinde olduğu görülmektedir. Bu iki ilçe genel sonuçlardan farklılaşırken aynı zamanda sosyopolitik kategorisi dışında birbirlerinden de farklı kavramsal sonuçlar ortaya koydukları belirlenmiştir.

Alt kategoriler itibarıyla yapılan incelemeler değerlendirildiğinde, ana kategorilerde farklılaşan ilçe gruplarının burada da yine farklılık gösterdiğini ve bu farklılıkların da büyük oranda yerel yönetimlerin siyasal temsillerini yansıttığını göstermiştir. Bu minvalde Çankaya'nın 4 ana kategoride ve Yenimahalle'nin 5 ana kategoride genel sonuçlardan ayrıştığı görülmektedir. Dolayısıyla kültür merkezleri için, siyasal ideolojinin bir pratiği olarak, özellikle kamusal istihdam ve çok boyutlu yaşamsal yönelimlerin toplumsal faaliyetler üzerinden tecessüm ettiği bir mekânsal üretim alanı olarak tanımlanabilir. Siyasal mekanizma bu tür farklı yönelim ve etkinlikleri hem yöneterek ve yönlendirerek hem de yeniden üretmektedir. Böylelikle siyasal mekanizma, kültür merkezleri vasıtasıyla territoryasını yaşamın neredeyse tüm alanlarına yaygınlaştırmakta ya da bu amaca yönelik ciddi çabalar sarf etmektedir (Şekil 2)i.

Çizelge 7. İlçeler bazında kursiyerlerin kültür merkezlerine ilişkin kullandıkları kavramların en yoğun olduğu alt kategoriler

\begin{tabular}{|c|c|c|c|c|c|c|c|c|}
\hline Kategoriler/ İlçele & Altındağ & Çankaya & Etimesgut & Keçiören & Mamak & Pursaklar & Yenimahalle & $\begin{array}{l}\text { Genel } \\
\text { Sonuç }\end{array}$ \\
\hline Aile gelişimi & Çocuk & Genç & Çocuk & Çocuk & Çocuk & Çocuk & Çocuk & Çocuk \\
\hline Bireysel gelişme & $\begin{array}{l}\text { Bireysel } \\
\text { gelişme }\end{array}$ & $\begin{array}{l}\text { Bireysel } \\
\text { gelişme }\end{array}$ & $\begin{array}{l}\text { Bireysel } \\
\text { gelişme }\end{array}$ & $\begin{array}{l}\text { Bireysel } \\
\text { gelişme }\end{array}$ & $\begin{array}{l}\text { Bireysel } \\
\text { gelişme }\end{array}$ & $\begin{array}{l}\text { Bireysel gelişme/ } \\
\text { Konfor }\end{array}$ & Konfor & $\begin{array}{l}\text { Bireysel } \\
\text { gelişme }\end{array}$ \\
\hline $\begin{array}{l}\text { Eğitim- } \\
\text { bilgilenme }\end{array}$ & Eğitim & Öğrenme & Öğrenme & Öğrenme & Eğitim & Öğrenme & Eğitim & $\begin{array}{l}\text { Ĕgitim/ } \\
\text { Öğrenme }\end{array}$ \\
\hline $\begin{array}{l}\text { Psiko-sosyal } \\
\text { gelişme }\end{array}$ & $\begin{array}{l}\text { İyi olma } \\
\text { hali }\end{array}$ & $\begin{array}{l}\text { İyi olma } \\
\text { hali }\end{array}$ & $\begin{array}{l}\text { İyi olma } \\
\text { hali }\end{array}$ & Arkadaşlık & İyi olma hali & $\begin{array}{l}\text { Arkadaşlık/ İyi } \\
\text { olma hali }\end{array}$ & Arkadaşlık & $\begin{array}{l}\text { İyi olma } \\
\text { hali }\end{array}$ \\
\hline Sağlıklı yaşam & $\begin{array}{l}\text { Sağlik ve } \\
\text { beslenme }\end{array}$ & Spor & Spor & Spor & Spor & Spor & $\begin{array}{l}\text { Spor / Sağlık } \\
\text { ve beslenme }\end{array}$ & Spor \\
\hline Sanatsal gelişme & $\begin{array}{l}\text { Sahne } \\
\text { sanatları }\end{array}$ & $\begin{array}{l}\text { Sanatsal } \\
\text { aktiviteler }\end{array}$ & $\begin{array}{l}\text { Sahne } \\
\text { sanatları }\end{array}$ & $\begin{array}{l}\text { Müzikve } \\
\text { dans }\end{array}$ & $\begin{array}{l}\text { Sahne } \\
\text { sanatları }\end{array}$ & $\begin{array}{l}\text { Müzik ve dans / } \\
\text { Sahne sanatları }\end{array}$ & Sahne sanatları & $\begin{array}{l}\text { Sahne } \\
\text { sanatları }\end{array}$ \\
\hline $\begin{array}{l}\text { Sosyo-ekonomik } \\
\text { gelişme }\end{array}$ & $\begin{array}{l}\text { Meslek } \\
\text { edinme }\end{array}$ & $\begin{array}{l}\text { Meslek } \\
\text { edinme }\end{array}$ & Dil & $\begin{array}{l}\text { Meslek } \\
\text { edinme }\end{array}$ & $\begin{array}{l}\text { Meslek } \\
\text { edinme }\end{array}$ & Dil/İstihdam & Dil & $\begin{array}{l}\text { Meslek } \\
\text { edinme }\end{array}$ \\
\hline $\begin{array}{l}\text { Sosyo-kültürel } \\
\text { gelişme }\end{array}$ & $\begin{array}{l}\text { Sosyal } \\
\text { etkinlik }\end{array}$ & $\begin{array}{l}\text { Kültürel } \\
\text { faaliyetler }\end{array}$ & $\begin{array}{l}\text { Kültürel } \\
\text { gelişim }\end{array}$ & $\begin{array}{l}\text { Kültürel } \\
\text { gelişim }\end{array}$ & $\begin{array}{l}\text { Sosyal } \\
\text { etkinlik }\end{array}$ & $\begin{array}{l}\text { Kültürel gelişim/ } \\
\text { Sosyal etkinlik }\end{array}$ & Sosyal etkinlik & $\begin{array}{l}\text { Kültürel } \\
\text { gelişsim }\end{array}$ \\
\hline Sosyo-politik & $\begin{array}{l}\text { Dini } \\
\text { konular }\end{array}$ & Politika & Tarih & Dini konular & Dini konular & Dini konular & Politika & $\begin{array}{l}\text { Dini } \\
\text { konular }\end{array}$ \\
\hline $\begin{array}{l}\text { Farklı kategori } \\
\text { sayısı }\end{array}$ & 2 & 4 & 2 & 2 & 1 & 1 & 5 & \\
\hline
\end{tabular}

Şekil 2'de, kavram ağında yer alan dokuz (9) kategori ve bu kategorilerin altında bulunan otuz sekiz (38) alt kategoride birbirinden farklı yüz doksan üç (193) kavram bulunmaktadır. Katılımcıların yararlandıkları kültür merkezlerine yönelik görüş ve düşüncelerini yansıtan bu kavramların tümü gündelik yaşam pratiği ile ilgilidir, fakat bu kavramlara yönelik etkin hizmetlerin hayata geçirilmesi tamamen siyasal ideolojilerin denetimi altındadır ve dolayısıyla ideolojiktir. Örnekleme alınan ilçeler arasında görülen farklılıkların olması da bu yaklaşımı teyit etmektedir. Örneğin seküler ya da muhafazakâr yaşam pratiklerine ilişkin etkinliklerin (dans, müzik, konser, tiyatro sinema, resim, hat, ney, tezhip, felsefe, edebiyat, tarih, dil, Kur'an kursu ve İslami sanatlar gibi) yürütülmesi tamamen ilgili kültür merkezinin bağlı olduğu belediye yönetimi teşkilatının siyasal görüşüne göre şekillenmektedir. 


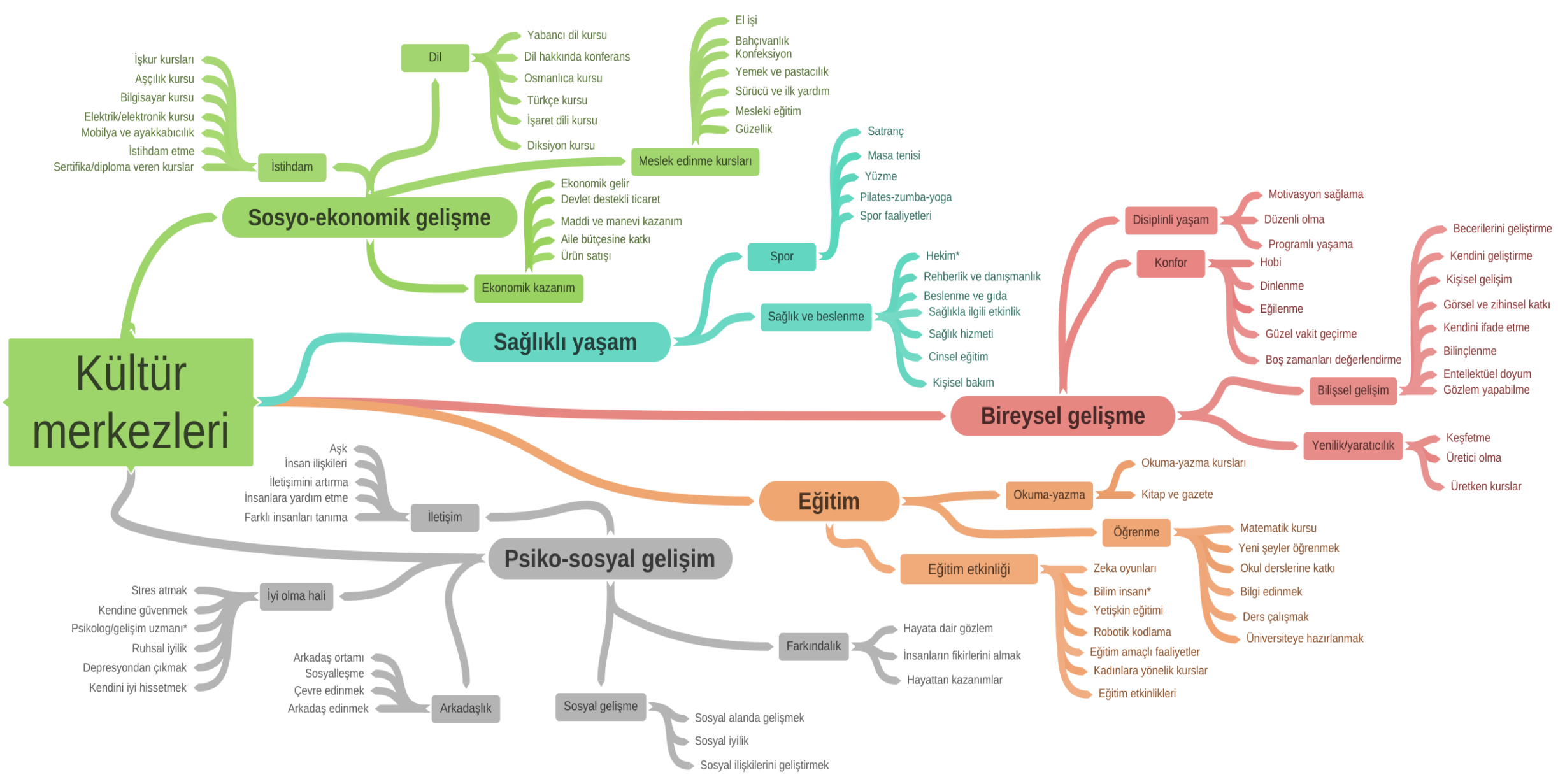

Şekil 2. Kavram ağı (a) 


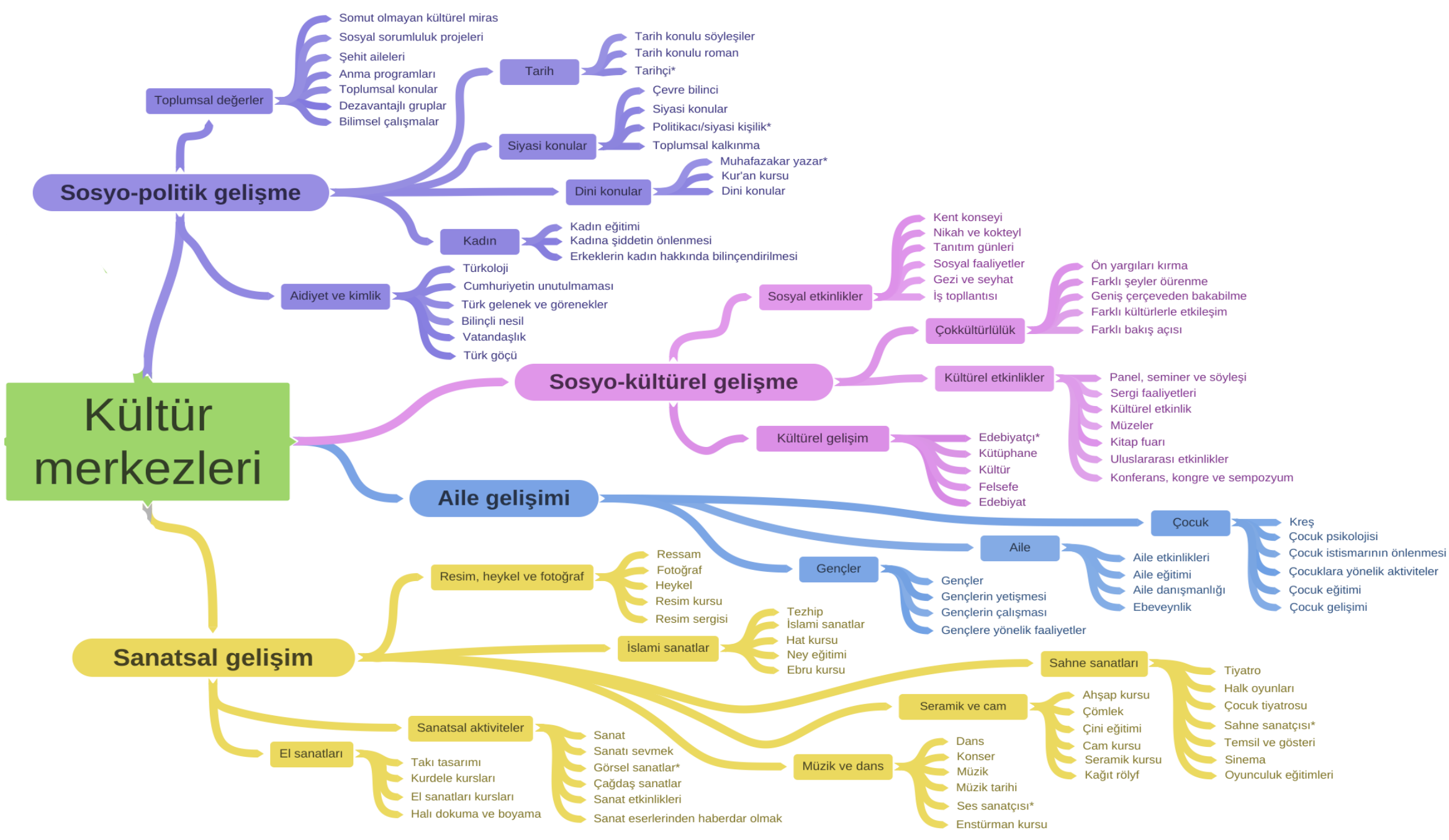

Sekil 2. Kavram ağ1 (b)- devam 
Bu hiyerarşik düzlemde her siyasal ideoloji kendi mekânsal üretimini gerçekleştirir ya da buna ilişkin faaliyetlere öncelik tanır. Dolayısıyla her iktidar, kendi siyasal ideolojisine uygun bir territorial alan üretmek adına, kültür merkezlerini ve bu merkezlerde yürütülen faaliyetlerin kapsam ve sınırını belirler. Bu nedenle kültür merkezlerinde yürütülen faaliyetler, bağlı bulundukları belediyelerin ve dolayısıyla ilgili siyasal partilerin program ve ideolojik yönelimlerine göre şekillenmektedir. Örnekleme alınan ilçelerde, belediyelere bağlı kültür merkezlerinde yürütülen farklı yönelime sahip etkinlikler de bu düşünceyi desteklemektedir. Bu bağlamda kültür merkezlerinin hem isimlendirilmesi hem de bu merkezlerde yürütülen faaliyetler, ilgili yönetimlerin siyasal ideolojilerine uygun ve belirli yaşamsal formların dizayn edildiği birer mekânsal üretim alanına dönüşmektedirler.

Kültür merkezleri örneklemi üzerinden gerçekleştirilen bu çalışmada elde edilen veriler içerik analiziyle çözümlenirken, elde edilen kavramların yukarıda belirtilen grupların dışında, aynı zamanda mevut durum ve öneri olmak üzere iki ayrı kategori altında ele alınabileceği düşünülmüştür. Buna göre katılımcılar, kültür merkezlerindeki mevcut durumun yanı sıra, olmasını istedikleri faaliyetleri de öneri olarak belirtmiştir. $\mathrm{Bu}$ iki kategoriye ilişkin oluşturulan kavramlar ilçe ve ana kategorilere göre ne tür niceliksel farklılıklar içerdikleri analiz edilmiş ve yorumlanmıştır (Çizelge 8).

Hem bu gruplar, hem de bunlarla ana kategoriler arasındaki istatistiki bağıntıları analiz etmek amacıyla bir karşılaştırma yapılmıştır. Buna göre; bireysel gelişme, eğitim-bilgilenme, psiko-sosyal, sosyo-ekonomik ve sosyo-kültürel gelişme kategorilerinde katılımcılar, mevcut yararlandıkları hizmetlere ilişkin olarak görüşlerini (bu kavramsal çerçevelerle) ifade etmişlerdir. K61'in ifadesiyle:

"Görüs açınız değişiyor. Arkadaş ortamınız genişliyor ve tabi ki geliş̧tiriyoruz kendimizi. Sürekli evde olmaktan ziyade arkadaşlarla birlikteyiz, gözlem yapıyoruz. Hayatta neler olup bittiğini gözlemleyebiliyorum." (K61, Etimesgut, K, 38, Ev hanımı).

Öte yandan katılımcılar; aile gelişimi, sağllklı yaşam, sanatsal gelişim ve sosyo-politik kategorilerinde ise yeni hizmetlerin sağlanmasına yönelik öneriler ortaya koymuşlardır. Katılımcıların görmek istedikleri ya da faydalanmak istedikleri (olmasını istedikleri veya önerdikleri) etkinlikler arasında en yüksek frekans oranına sahip tematik alt boyutlar ise; sahne sanatlar, kültürel gelişim, çocuk, müzik ve dans alt kategorileri olarak tespit edilmiştir.

Çizelge 8, ilçeler itibariyle Mevcut durum ve Öneriler arasındaki ayırımı yapmak amacıyla oluşturulmuştur. Burada ana kategoriler itibarıyla katılımcıların dile getirdiği kavramların ilçede sayılan tüm kavramlar içerisindeki payına göre bir derecelendirme yapılmıştır. İlçeler arasında en çok farklılaşmanın olduğu kategoriler aile gelişimi, psiko-sosyal gelişme, sanatsal gelişme ve sosyoekonomik gelişmedir. Buna göre aile gelişimi kategorisinde en fazla öneri Altındağ ilçesinden gelmiştir. Psiko-sosyal gelişme kategorisinde ilçeler arasında dengeli bir dağılım oluşurken, Çankaya ve Yenimahalle ilçelerinde bu kategoride hem mevcut durum hem de öneri olarak ifade edilen kavramların daha az olduğu belirlenmiştir. Diğer yandan gelir seviyesi düşük ilçelerde sosyo-ekonomik gelişme kategorisinde mevcut duruma ilişkin kavramlar görece yüksek olsa bile katılımcılar bu kategoriyle ilgili öneri amaçlı kavramları da sıklıkla kullandıkları belirlenmiştir.

Sanatsal gelişme kategorisinde ise Çankaya ilçesinde hem Mevcut durum hem öneri amaçlı kavramlar yoğun olarak kullanılmıştır. Aynı düzeyde olmasa da Yenimahalle ilçesinde de sanatsal 
gelişmeye ilişkin mevcut durum ve öneri kavramlarının sayısı fazladır. Bununla birlikte Altındağ, Keçiören ve Pursaklar ilçelerinde kültür merkezlerinden yararlanan kursiyerlerin sanatsal gelişme kategorisindeki yeni faaliyetlerle ilgili önerilerinin de olduğu tespit edilmiştir.

Çizelge 8. Kursiyerlerin kültür merkezlerine ilişkin mevcut durum ile bu merkezlere ilişkin önerilerinin karşılaştırılmas

\begin{tabular}{|c|c|c|c|c|c|c|c|c|c|c|c|c|c|c|c|c|}
\hline & \multicolumn{2}{|c|}{ Altındağ } & \multicolumn{2}{|c|}{ Çankaya } & \multicolumn{2}{|c|}{ Etimesgut } & \multicolumn{2}{|c|}{ Keçiören } & \multicolumn{2}{|c|}{ Mamak } & \multicolumn{2}{|c|}{ Pursaklar } & \multicolumn{2}{|c|}{ Y.mahalle } & \multicolumn{2}{|c|}{ Toplam } \\
\hline & M & Ö & M & Ö & $\mathrm{M}$ & Ö & M & Ö & M & Ö & $\mathrm{M}$ & Ö & $\mathrm{M}$ & Ö & $\mathrm{M}$ & Ö \\
\hline Aile gelişimi & $2 \%$ & $14 \%$ & $0 \%$ & $1 \%$ & $4 \%$ & $6 \%$ & $1 \%$ & $3 \%$ & $1 \%$ & $6 \%$ & $4 \%$ & $7 \%$ & $1 \%$ & $3 \%$ & $2 \%$ & $6 \%$ \\
\hline Bireysel gelişme & $5 \%$ & $2 \%$ & $7 \%$ & $1 \%$ & $2 \%$ & $1 \%$ & $9 \%$ & $2 \%$ & $7 \%$ & $3 \%$ & $3 \%$ & $0 \%$ & $5 \%$ & $5 \%$ & $6 \%$ & $2 \%$ \\
\hline Eğitim-bilgilenme & $5 \%$ & $4 \%$ & $6 \%$ & $2 \%$ & $3 \%$ & $5 \%$ & $7 \%$ & $5 \%$ & $1 \%$ & $3 \%$ & $11 \%$ & $4 \%$ & $3 \%$ & $4 \%$ & $5 \%$ & $4 \%$ \\
\hline Psiko-sosyal gelişme & $11 \%$ & $2 \%$ & $3 \%$ & $1 \%$ & $10 \%$ & $2 \%$ & $13 \%$ & $0 \%$ & $7 \%$ & $2 \%$ & $14 \%$ & $3 \%$ & $10 \%$ & $0 \%$ & $9 \%$ & $1 \%$ \\
\hline Sağlıklı yaşam & $3 \%$ & $7 \%$ & $1 \%$ & $1 \%$ & $2 \%$ & $2 \%$ & $5 \%$ & $4 \%$ & $0 \%$ & $4 \%$ & $1 \%$ & $3 \%$ & $0 \%$ & $2 \%$ & $2 \%$ & $4 \%$ \\
\hline Sanatsal gelişme & $2 \%$ & $9 \%$ & $19 \%$ & $23 \%$ & $10 \%$ & $12 \%$ & $3 \%$ & $12 \%$ & $10 \%$ & $8 \%$ & $0 \%$ & $14 \%$ & $21 \%$ & $10 \%$ & $9 \%$ & $12 \%$ \\
\hline Sosyo-ekonomik gelişme & $10 \%$ & $6 \%$ & $1 \%$ & $1 \%$ & $8 \%$ & $5 \%$ & $10 \%$ & $6 \%$ & $10 \%$ & $9 \%$ & $16 \%$ & $4 \%$ & $0 \%$ & $3 \%$ & $8 \%$ & $5 \%$ \\
\hline Sosyo-kültürel gelişme & $4 \%$ & $3 \%$ & $14 \%$ & $8 \%$ & $10 \%$ & $4 \%$ & $5 \%$ & $7 \%$ & $11 \%$ & $7 \%$ & $5 \%$ & $7 \%$ & $9 \%$ & $11 \%$ & $9 \%$ & $6 \%$ \\
\hline Sosyo-politik & $1 \%$ & $9 \%$ & $5 \%$ & $9 \%$ & $3 \%$ & $11 \%$ & $1 \%$ & $5 \%$ & $1 \%$ & $11 \%$ & $0 \%$ & $5 \%$ & $3 \%$ & $10 \%$ & $2 \%$ & $9 \%$ \\
\hline
\end{tabular}

Tüm bu analizler, sosyo-ekonomik yapılarına bağlı iş ve istihdama ilişkin beklentilerin kültür merkezlerinden yararlanan katılımcıların tercihlerini etkilediğini göstermiştir. Bununla birlikte kültür merkezlerinin ana kullanım amaçlarından birisi olan sanatsal faaliyetlere yönelik hizmetlerin yetersiz olduğu ilçelerde dahi bu kategoride daha fazla hizmet almaya dönük talepler oluşmaktadır. Diğer bir ifadeyle kültür merkezinden yararlanan kursiyerler, her ne kadar yerel yönetimlerin belirlediği kapsam ve içerikteki hizmetlerden faydalansalar bile, bunların değiştirilmesi ya da geliştirilmesi yönünde taleplerini de dile getirmişlerdir.

\subsection{Yönetici ve Kültür Merkezlerinden Yararlanan Kursiyerlerin Görüşlerini Yansıtan \\ Verilerin Karşılaştırılması}

Yönetici anketlerine ilişkin analizler, sadece ana kavram kategoriler bazında yapılmıştır. Bu ana kategoriler itibarıyla kursiyer ve yönetici anketlerinin sonuçları karşılaştırıldığında aile gelişimi, eğitim ve bilgilenme, sanatsal, sosyo-ekonomik ve sosyo-kültürel gelişme kategorilerinde, yöneticilere ait kavramların frekans oranlarının daha yüksek olduğu görülmektedir. Bireysel gelişme, psiko-sosyal gelişme, sağllkll yaşam ve sosyo-politik kategorilerinde ise kültür merkezinden yararlanan kursiyerlerin kullandıkları kavram yoğunluğunun daha yüksek olduğu belirlenmiştir. Böylelikle kursiyerlerin, yöneticilerden farklı olarak kültür merkezlerinin sunduğu sanatsal ve kültürel hizmetlerin ötesinde Bireysel gelişme, psiko-sosyal gelişme ve sosyo-politik unsurları öne çıkardıkları görülmektedir.

Yönetici ve kursiyer görüşme formlarının bulguları ilçe bazında karşılaştırıldığında önemli benzerliklerin olduğu görülmektedir (Şekil 3). Örneğin Altındağ, aile gelişimi ve sağllkl yaşam kategorilerinde hem kursiyer hem de yönetici anketlerinde kavram frekanslarının en yüksek olduğu ilçe olmuştur. Benzer bir durum sanatsal gelişme kategorisi için Çankaya ve sosyo-ekonomik gelişme kategorisi için Pursaklar ilçeleri için de geçerlidir. En yüksek değerlere sahip olmasa da Pursaklar ve Etimesgut'ta aile gelişimi ve psiko-sosyal gelişim, Altındağ'da bireysel gelişim, Keçiören'de eğitim ve bilgilenme ile sağllkl yaşam, Yenimahalle'de sanatsal gelişim ve sosyo-kültürel gelişme ile Mamak’ta sosyo-ekonomik gelişme öne çıkan kategoriler arasında yer almıştır. Dolayısıyla farklı anket soruları da olsa bu iki farklı grup, kültür merkezlerine ilişkin aynı yönde ve eğilimde kavramları tercih ettikleri tespit edilmiştir. 


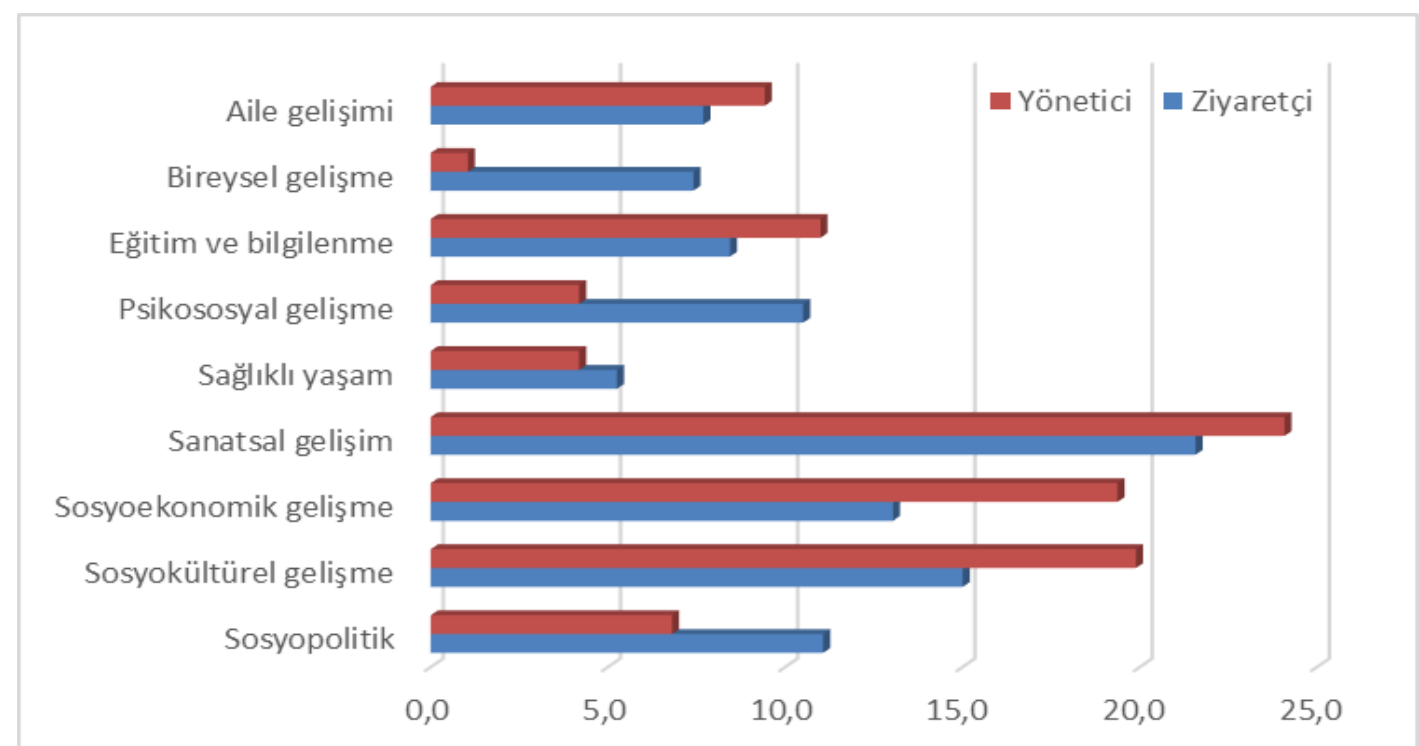

Şekil 3. Kursiyer ve yöneticilerin kültür merkezlerine ilişkin görüşlerinin, kategori ve frekans oranlarına göre karşılaştırılması

Yukarıdaki arz-talep dengesinin aslında kendiliğinden oluşan değil yönlendirilmiş bir mekanizma olduğu görülebilmektedir. Beş kategoride yöneticilerin, diğer dört kategoride ise kültür merkezlerinden yararlanan katılımcıların/kursiyerlerin daha talepkar oldukları görülmektedir (Şekil 3). $\mathrm{Bu}$ alanda düzenleme ve karar verme yetkisi, yöneticilerin bağlı bulundukları siyaset mekanizması olduğu için, kültür merkezindeki hizmet tasarımları son kertede siyasal ideolojinin kapsam ve yaklaşımına uygun pratiklerle devam etmektedir. Böylelikle kültür merkezlerinin isimleri ve içindeki faaliyetlerin belirlenmesi ile siyasal ideoloji tekrar tekrar üretilmekte ve ilçeler için tek bir siyasal yaklaşım hâkim ideoloji haline gelmektedir. Bunun sonucunda kültür merkezinden yararlanan katılımcılar/kursiyerler, kendi ideolojik yaklaşımları ile örtüştügü sürece hizmetlerden yararlanmakta, aksi takdirde diğer ilçelerdeki kültür merkezlerine yönelebilmektedirler. Kursiyerler kullandıkları kültür merkezinden yine kendi hayat görüşlerine uygun faaliyetler talep etmekte, böylelikle yerel yöneticiler halkın taleplerine göre faaliyetleri belirleyebilmektedir. Ancak bunun sonucunda kamusal hizmet alanı olarak kültür merkezlerine verilen isimlerde olduğu gibi, kültürel çeşitliliği ve çokkültürlülüğü yansıtmak yerine hâkim siyasal ideolojinin adeta birer aygıtı haline dönüşmektedirler.

$\mathrm{Bu}$ çalışmada incelenen ilçeler içerisinde bu genellemenin tek istisnası Mamak ilçesidir. Mamak çokkültürlülük ve kadın alt kategorilerinde belirgin bir farklılığı kültür merkezleri aracılığıyla yürüten bir siyasal anlayışa sahiptir. Bunun yanında birçok kategori ve alt kategoriden birbirleriyle farklılaşan, "Keçiören, Pursaklar" ile "Yenimahalle, Çankaya" ilçelerinden farklı olarak her iki grup ilçenin ortak tercihlerini ortaya koyduğu ve buna ilişkin temsillerin hayata geçirildiği görülmektedir. Alan araştırmasında temin edilen verilerin analizi ve sahada yapılan gözlemler birlikte değerlendirildiğinde, seküler ve milliyetçi-muhafazakâr yaşamı önceleyen ve bu tür pratikleri kültür merkezleri aracılığıyla hayata geçiren bir genel yaklaşım bulunmaktadır. Kültür merkezlerine verilen isimler de bunun tipik örneklerindendir. 
Dolayısıyla kültür merkezlerinin isimlerinde tercih edilen siyasal/ideolojik yaklaşımlar ile bu merkezlerdeki faaliyetlerin önemli ölçüde örtüştüğü ve kültür merkezlerindeki bu tür faaliyet tasarımlarının çokkültürlülük ve toplumun bütününü temsil etmekten uzak kaldığı tespit edilmiştir. Kültür merkezleri üzerinden hayata geçirilen bu tür ideolojik faaliyetler toplumsal bütünlüğe hizmet etmediği gibi, birlikte yaşama becerisini sekteye uğratabileceği de unutulmamalıdır.

\section{Sonuç ve Tartışma}

Kültür merkezlerine verilen isimler; toplumların yaşam tarzı, düşünce yapısı ve kültürleri hakkında bilgi verir. Salt isimlendirme ve mevcut etkinlikler üzerinden yapılan bu inceleme ve tespit çalışmasında kültür merkezlerinin yöneticileri ve bu merkezlerden yararlanan katılımcılarla yapılan görüşmeler neticesinde bir adım öteye taşınmıştır. Katılımcılarla yapılan görüşmelerde kültür merkezlerinin isimleri ile bu merkezlerde yürütülen faaliyetler ve bu faaliyetlerden yararlanan katılımcıların yaklaşımları arasında ne tür ilişkiler olduğu elde edilen verilerle çözümlenmeye çalış1lmıştır.

Kültür merkezlerinden yararlanan katılımcılarla ilgili değişkenler incelendiğinde bu merkezlerin çok amaçlı işlevler üstlendiği söylenebilir. Ayrıca, gelir seviyesi düşük ilçelerde meslek edinme, ek gelir sağlama, sertifikalı kurslara katılma ve iş hayatına hazırlık (özellikle yabancı dil olarak İngilizcenin yanı sıra bilgisayar kullanma sertifikaları vb.) amaçlı kullanımların oldukça fazla olduğu tespit edilmiştir. Gelir seviyesi görece yüksek ilçelerde ise sanatsal faaliyetler ve sergiler ön planda olup, kültür merkezlerinin sosyo-kültürel paylaşım mekânları olarak hizmet verdiği belirlenmiştir. Mamak ve Çankaya ilçe belediyelerinde yer alan kültür merkezleri bu verili durum ve analiz sonuçlarını sarih bir şekilde destekleyen örneklerdendir.

Çankaya ve Yenimahalle belediyelerine bağlı kültür merkezlerinde gerçekleştirilen çeşitli etkinliklere iştirak eden katılımcıların daha çok sanatsal gelişim ve sosyo-kültürel faaliyetlere yöneldikleri ve bu alanlarla ilgili eğitimlere katıldıkları belirlenmiştir. Buna karşın Altındağ ve Etimesgut başta olmak üzere, çalışmaya dâhil edilen diğer merkez ilçe belediyelerine bağlı kültür merkezlerinden yararlanan katılımcıların ise, daha çok eğitim ve istihdama yönelik belirli bir deneyim ve uzmanlık gerektiren alanlarla ilgili sertifika almak amaciyla kültür merkezlerinin çeşitli eğitim kurslarından yararlandıkları belirlenmiştir. Bu iki örnekte de belirtildiği gibi, kültür merkezleri aslında -arz ve talep ilişkisinin ötesinde- bulundukları ilçe belediyelerinin (belediye yönetiminin) siyasal temsilinin bir üretim kanalı olarak da işlev görmektedir. Örneğin Altındağ ilçesinde Hüseyin Gazi Kültür Merkezinde yürütülen kamusal faaliyetlerden yararlanan herhangi bir katılımcının islami sanatlar ve dini konulara (muhafazakâr/ mütedeyyin yazarlara ulaşmak, Kur'an kursuna gitmek ve dini konularda bilgilenmek gibi) ilişkin talepleri kabul görebilir ve bu tür yönelimler desteklenebilir. İktidar ile kamu ilişkisi açısından bu olağan bir arz talep konusudur. Bu tür talepler, hem seküler hem de mütedeyyin ya da milliyetçi bir belediye yönetiminden de talep edilmesi durumunda muhtemel iki seçenek devreye girecektir. Ya kamusal bir hizmet için gereklidir düşüncesiyle böyle bir kurs hizmeti mevcut iktidarın (merkezi iktidar ya da otoriteyle ters düşmemek koşuluyla) belirlediği düzende bir yapılanmayla gerçekleştirilecek ya da talepte bulunan vatandaş veya herhangi bir kamu tüzel kişiliğine, belirli bir gerekçe ileri sürülerek, talepleri geri çevrilecektir. Her iki durumda da (talebe yönelik olumlu 
ya da olumsuz cevapla) iktidarın hayata geçireceği ideolojik aparatlar, kamusal hizmet olarak toplumu yönlendirecek türden bir üretim aygitı olacaktır.

Şurası açık ki, mütedeyyin, muhafazakâr, milliyetçi ya da seküler bir belediye yönetiminin kültür merkezlerinde bir kamu hizmeti olarak yürüteceği (kamuoyundan talep olsun ya da olmasın) herhangi bir eğitimi kendi iktidarı için bir aparat olarak işlevselleştirmesi, en azından bu türden bir çabanın güdülmesi varsıl bir hakikattir. Çünkü kültür merkezleri yoluyla verilen bir kursun ya da eğitimin, ilgili belediye ve iktidar yönetimince nasıl tasavvur edildiği ve hangi kapsamla oluşturulduğu önemlidir. Yukarıda verilen (olağan) örnekten hareketle, vatandaşın talep etmesi ya da belediyelerin kamu hizmeti olarak Kur'an kursunu açması ve vatandaşların dini yönelim ve ihtiyaçlarının karşılanması olağan bir hizmettir. Ancak şu ayrıntı önemlidir: Bu tür eğitim ya da kültürel faaliyetlerin gerçekleştirilmesinde izlenecek müfredatın tematik kapsamı nasıl olacaktır. En radikal yönelimlerden en mutedil ve birleştirici geleneklere kadar uygulanacak olan programın niteliği ne olacaktır? İşte kamunun yönelimini önemli ölçüde etkileyebilecek temel konu budur. Çünkü esas konu yürütülecek hizmetin muhtevası ve ideolojik temsil ölçeğidir ve bu durum neredeyse tamamen iktidarın ideolojik tasavvuruyla yol alır. Araştırma bulgularından olan Çağdaş sanatlar ve İslami sanatlarla ilgili pratikler tipik örneklerdendir. Dolayısıyla belediyelerin kültür merkezleri aracılığıyla çeşitli kamusal hizmetleri (sosyo-kültürel, psiko-sosyal, sosyo-ekonomik, eğitim vb. konuları) hayata geçirmesi, aynı zamanda kendi iktidarlarının ideolojik üretiminin devamı ve perçinleş(tiril)mesi anlamına gelmektedir. Tüm bu faaliyetlerin gerçekleştirildiği kültür merkezlerinin görünürlüğü ve tanınması için de ideolojik amacı yansıtan bir isimlendirme pratiği hayata geçirilir. Bu aynı zamanda üretilen politikaların bir imajı ve temsilin görünürlüğünü de ifade etmektedir. Örneğin Çankaya ve Yenimahalle ilçelerinde Nazım Hikmet Ran, Altındağ, Keçiören, Mamak ilçelerinde ise Necip Fazıl Kısakürek isminin öne çıkması tam da iktidar-mekân ilişkiselliğini özetler niteliktedir. Kısacası kültür merkezleri aracıllğıyla hayata geçirilen tüm yapılanmaların arka planında, topluma yönelik bir ideolojik tasarım vardır.

Araştırmada, kültür merkezlerine yönelik taleplerde iki farklı yönelim dikkat çekmektedir. Birincisi, Çankaya ve Yenimahalle ilçelerindeki katılımcıların daha çok sosyo-kültürel ve sanatsal faaliyetlere ilişkin kültürel hizmetleri talep etmeleridir. Buna karşın Altındağ, Keçiören, Pursaklar ve Mamak ilçelerindeki katılımcılar ise daha çok sosyo-ekonomik ve psiko-sosyal eksenli taleplerle kültür merkezlerinden yararlandıkları belirlenmiştir. Bu iki yönelim arasındaki farkın temelinde, hem sınıfsal hem de bu pratiklerin dayandığı siyasal düşünce kodlarının toplumsal yaşam pratiklerindeki etkinliği vardır. Benzer sonuçlar yöneticilerin görüşlerinde daha net bir şekilde görülmektedir. Çankaya ilçesindeki kültür merkezinde görevli yöneticilerin sanatsal gelişsim $(\% 57,1)$ ile ilgili yönelim ve hizmet pratiklerini tanımlayan ifadelerinin, bu ilçedeki merkezleri ziyaret eden katılımcıların beklentilerinin $(\% 42,1)$ de önünde olması, belediye yönetiminin sanatsal faaliyetlere yönelik pratiklerinin oldukça etkin olduğunu kanıtlar niteliktedir. Tam aksine Altındağ (10,7 ile 10,9), Keçiören (12,9 ile 15,5), Mamak (11,9 ile 18,3) ve Pursaklar (\%0 ile \%13,5) ilçelerindeki yöneticilerin ise, sanatsal gelişim konularına yönelik düşünce ve kavramsal ifadelerinin, bu ilçelerdeki kültür merkezlerinden yararlanan katılımcıların taleplerinin gerisinde kalması dikkat çekicidir. Bu açıklamalara ek olarak, hiç şüphesiz ilçelerin tarihsel gelişimi ve merkez-çevre ilişkilerinin de göz ardı edilmemesi gerekir. Cumhuriyetin ilanıyla birlikte, devletin en üst kurum ve yönetim kadrosunun ikamet ettiği ve seküler yaşam tarzının 
Çankaya ilçesiyle birlikte anılması da önemli bir ayrıntı olarak eklenebilir. Tüm bu verili durum ve niceliksel analizler, kültür merkezlerindeki aktivitelerin ideolojik temelli dünya görüşlerinin birer yansıması olduğunu da teyit etmektedir. Böylelikle siyasal ideolojiler, topluma yönelik pratiklerde doğrudan bir dayatmada ya da "baskıcı aygitlardan" (Althusser, 2014) ziyade, toplumsal varlığın ve bütünlüğün vazgeçilmez unsurları olarak kabul gören özellikle toplumsal aidiyet, din, mezhep, kimlik, ortak tarih, eğitim ve birliktelik gibi ideolojik aparatlarla adeta kör bilinçler yaratılmakta ve bu ideolojik körlükler üzerinden kamusal alan re'sen dizayn edilmektedir.

Araştırma verilerinden elde edilen en önemli sonuç, hiç şüphesiz siyasal ideolojilerin kamusal alana yönelik kültürel hizmetlerde sahip oldukları ideolojilerin bir pratiği olduğu ve yürütülen hemen tüm faaliyetlerin ilgili siyasal ideolojiye uygun bir territoryanın devamını sağlamak üzere gerçekleştirildiğidir. Bu çerçevede, birinci gruptaki Çankaya ve Yenimahalle ilçe belediyelerinin (bağlı oldukları siyasal örgüt ve politikaları), daha çok sanatsal ve sosyo-kültürel eksenli bir toplumsal gelişim modeliyle kültür merkezlerindeki faaliyetleri sürdürdügü görülmektedir. İkinci grup ilçeler olarak Altındağ, Keçiören ve Pursaklardaki kültür merkezlerinde yürütülen faaliyetlerde ise daha çok aile ve sosyo-ekonomik temelli düşüncelere ilişkin kavramlar dikkat çekmektedir. Bu kategorik analiz aynı zamanda sosyo-ekonomik durum analiziyle ilgili kısa bir açıklamayı da gerekli kılmaktadır. Ankara'nın merkez ilçeleri arasındaki sosyo-ekonomik farklılaşmalar değerlendirildiğinde, çalışmada ele alınan 9 ilçenin, 3 farklı kademede temsil edildiği görülmektedir. Sanayi ve Teknoloji Bakanlığı (2020) tarafından hazırlanan ve Türkiye'deki ilçeleri 6 kademeye ayıran İlçelerin Sosyo-ekonomik Gelişmişlik Sıralaması Araştırması'na (SEGE-2017) göre Çankaya, Altındağ ve Yenimahalle ilçeleri birinci kademe; Etimesgut, Keçiören, Gölbaşı, Sincan ve Mamak ilçeleri ikinci kademe; Pursaklar ilçesi ise üçüncü kademe ilçe kategorisindedir (Çizelge 9).

Çizelge 9. Ankara'daki merkez ilçelerin (örneklem grubunun) sosyo-ekonomik gelişmişlik siralamas1

\begin{tabular}{|c|c|c|c|c|c|c|}
\hline \multirow[b]{2}{*}{ İlçe Ad1 } & \multicolumn{3}{|c|}{ SEGE (2017) } & \multicolumn{3}{|c|}{ İGE-İ (2017) } \\
\hline & $\begin{array}{l}\text { Türkiye } \\
\text { Siralama }\end{array}$ & $\begin{array}{c}\dot{\mathrm{I}} \mathrm{l} \\
\text { siralama }\end{array}$ & Kademe & $\begin{array}{l}\text { Türkiye } \\
\text { Siralama }\end{array}$ & $\begin{array}{c}\dot{\mathrm{I} l} \\
\text { siralama }\end{array}$ & Kademe \\
\hline Çankaya & 3 & 1 & 1 & 3 & 1 & ÇYİG \\
\hline Altındağ & 7 & 2 & 1 & 40 & 4 & YİG \\
\hline Yenimahalle & 11 & 3 & 1 & 12 & 2 & ÇYİG \\
\hline Etimesgut & 67 & 4 & 2 & 62 & 5 & YİG \\
\hline Keçiören & 73 & 5 & 2 & 25 & 3 & ÇYİG \\
\hline Gölbaşı & 81 & 6 & 2 & 89 & 8 & OİG \\
\hline Sincan & 106 & 8 & 2 & 74 & 7 & YİG \\
\hline Mamak & 127 & 9 & 2 & 92 & 9 & OİG \\
\hline Pursaklar & 239 & 16 & 3 & 149 & 15 & DİG \\
\hline
\end{tabular}

İnsani Gelişme Vakfı (Şeker, Bakış ve Dizeci, 2018) tarafından ilçeler düzeyinde yapılan İnsani Gelişme Endeksi-İlçeler (İGE-İ) çalışmasına göre Çankaya, Yenimahalle ve Keçiören ilçeleri çok yükssek insani gelişmişlik (ÇYİG) düzeyine; Altındağ, Etimesgut ve Sincan ilçeleri yüksek insani gelişmişlik (YİG) düzeyine sahiptir. Gölbaşı ve Mamak orta insani gelişmişlik (OİG) düzeyine ve Pursaklar ise düşük insani gelişmişlik (DİG) düzeyine sahiptir. Altındağ ve Gölbaşı ilçelerinin SEGE2017 araştırmasında İGE-İ çalışmasına kıyasla daha üst sıralarda olmasının nedeni, bu araştırmada kullanılan göstergelerin dikkate aldığı kamusal hizmetler (eğitim, sağlı, bankacılık, tiyatro, opera) bakımından Ankara'nın tamamına hizmet veren kurum ve kuruluşlara ev sahipliği yapmaları ile ilgilidir. 
Bu nedenle SEGE ilçe sıralamasında sırasıyla ikinci ve altıncı olan Altındağ ve Gölbaşı ilçeleri, İnsani Gelişmişlik Endeksi (İGE) çalışmasında dördüncü ve sekizinci sıralarda yer alabilmiştir.

Periferide yer alan ve ekonomik olarak daha düşük gelir düzeyine sahip ilçelerde katılımcıların yönelimi de doğal olarak bu dezavantajlı durumun giderilmesine yönelik girişimler olacaktır. Bu bağlamda, özellikle kültür merkezlerindeki yöneticilerin görüş ve düşünceleri değerlendirildiğinde birinci grup ilçelerdeki kültür merkezlerinde daha çok seküler yaşam tarzını önceleyen ve bu alanla ilgili faaliyetlere ağırlık verildiği, ikinci grup ilçelerde ise daha çok sosyo-ekonomik ve muhafazakâr yaşam pratiğini (Aile kategorisi gibi) önceleyen kültürel etkinliklerin öne çıktığı görülmektedir. Bu durum hem siyasal ideolojiler ile ekonomik refahın simbiyotik bağıntısını afişe etmekte, hem de sosyo-kültürel ve sosyo-ekonomik gelişim için en önemli gerekliliklerden biri olduğunu göstermektedir. Özellikle yüksek gelir düzeyine seküler bir yaşam tarzına sahip olan birinci grup ilçelerdeki katılımcıların sosyal ve sanatsal gelişime yöneldikleri görülmektedir. Buna karşın düşük gelir düzeyine sahip ikinci grup ilçelerde, özellikle istihdam ve meslek edinme kursları gibi ekonomiyle doğrudan bağlantılı yönelimlerin olması ise mütedeyyin, muhafazakâr ve milliyetçilik gibi çeşitli siyasal kültürlerin belirmesinde kaldıraç görevi üstlendiği görülmektedir. Diğer bir ifadeyle birinci grup ilçelerde sosyokültürel ve sanatsal gelişime yönelik bir eğilim bulunurken, ikinci grup ilçelerde ise sosyo-ekonomik, psiko-sosyal ve aile gelişimi kategorilerine yönelik eğilimin yüksek olması aynı zamanda belirli bir siyasal ve kültürel ideolojinin zemin taşlarını döşenmesine de alan açmaktadır.

Sonuç olarak, çalışmada yerel siyasal erklerin ideolojik duruşu ve önceliklerinin, mekân isimlerinin belirlenmesinde en önemli unsurlardan biri olduğu belirlenmiştir. Yerel yönetimler mekân isimlerini, eş zamanlı işleyen bir siyasal/ideolojik bütünleşmenin yanı sıra aynı zamanda bir ayrışma aracı olarak da kullanmaktadır. Aynı toplumda yaşayan ve etnik, dinsel, mezhepsel, inançsal, siyasal aidiyetleri bakımından farklılaşan bireylerin görüş ve değerlendirmeleri dikkate alınmadan belirlenen bu isimlendirmeler, yerel yönetimlerin ideolojisine sahip bireyler açısından birleştirici olduğu varsayılsa da, tam aksine "diğerleri ya da ötekiler" açısından ise ayrıştırıcı bir rol üstlenmektedir. Dolayısıyla ideolojik açıdan "biz" ve "öteki” arasına çizilen bu sınır tespitinin belirginleş(tiril)mesi, toplumsal bütünlüğe zarar vermektedir.

Bu tercihler neticesinde başkent Ankara'nın kültürel peyzajında geçmişten bugüne, yan yana gelebilmiş farklılıkların/çeşitliliğin yerel yönetimler tarafından azaltıldığı, yönettikleri alanda çoğulcu bir anlayış ve siyasal pratiklerden ziyade, çoğunlukçu ve hatta tek bir kimlik anlayışı üzerinden kültürel inşaya yöneldikleri, alan çalışmasında toplanan verilerin değerlendirmesiyle de kanıtlanmıştır.

\footnotetext{
Notlar

iAraştırmanın analizini yansıtan kavram ağı bir bütün olarak okunmalıdır. Kültür Merkezleri ana kavramını çevreleyen tüm ana ve alt kategoriler birlikte değerlendirilmelidir. Sayfa boyutuna ilişkin sınırlılık nedeniyle Şekil 2 tek sayfada ve bir bütün olarak değil de iki ayrı sayfada verilebilmiştir.
} 


\begin{tabular}{ccc} 
Coğrafi Bilimler Dergisi & Cogrrafi \\
Bilimler & Dergisi \\
\hline & Turkish Journal of Geographical Sciences & e-ISSN:1308-9765 \\
\hline
\end{tabular}

Reproduction of Cultural Identity in Urban Space: The Case of Cultural Centers in Ankara ${ }^{1}$

\author{
Nurettin Özgen ${ }^{\mathrm{a}}$, Volkan İdris Sarı ${ }^{\mathrm{b} *}$
}

\title{
EXTENDED ABSTRACT
}

\section{Introduction}

Human memory needs space while recording past experiences and tends to spatialize events (Köşker, 2018: 89). Social memory is constantly updated depending on time, place and historical conditions. In this sense; remembrance, language, history and culture are factors that affect the collective memory of societies. Urban spaces, with their unique features, make these elements live and renew themselves. Thus, urban memory provides continuous evolution and transformation depending on changes in space (Ünlü, 2017: 78) and reveals identity elements that distinguish inhabitants of this space from others. Having a determining role on human behavior, culture initiates a social construction process by affecting space. Therefore, physical space is not an empty space independent from symbolic meanings, and cultural glasses are needed to read it correctly (Öncü and Weyland, 2016: 31). In this context, the formation process for the identity of a place is generally a historical phenomenon (Tekeli, 2009: 84). The dominant discourses in society affect social life directly and indirectly (Günay-Aktaş and Yayla, 2018: 241).

The combining and parsing functions of identity run in tandem and simultaneously (Bauman, 2017: 97). Hence, the concept of identity emerges with the interaction of two basic processes: the first is internal reinforcement of identifying and revealing similarities, and the second is an external distinction over differences from others (Özgen, 2018: 113). Cities that bring differences together in same space contain various contradictions within their structure, and these contradictions are reproduced in space and they form spaces of "segregation” (Aliağaoğlu and Uğur, 2016: 217).

The city develops its own identity through many tangible and intangible elements (Madanipour, 2013: 52). The urban toponomy, which includes the names of places and spaces, is one of the intangible identity elements of city (Baysan, 2019: 281). With naming, the surrounding becomes a part of the identity (Mai, 2016: 112). Although names of places alike simple choices, they actually reflect the

\footnotetext{
* Corresponding Author: Volkan İdris Sarı, volkan.i.sari@ gmail.com

a Ankara University, Faculty of Languages, History and Geography, Department of Geography, Ankara, Turkey, http://orcid.org/0000-0001-9191-1579.

b Ankara University, Social Sciences Institute, Ankara, Turkey, http://orcid.org/0000-0001-7032-8069.

1 This article was prepared on the basis of the research project entitled "Place Naming in the Context of Political Ideologies: The Case of Cultural Centers in Ankara", which was awarded the Koç University VEKAM 2019 Research Award, and an article revealing the results of the aforementioned research has been accepted for publication in the Journal of Ankara Studies in the June 2021 issue.
} 
values, beliefs, passions, pains, bliss of cultures that produce these names (Gülbetekin, 2017: 32). On urban scale, important milestones, current policies, people or events in memory the city, and the elements that are effective in the formation of urban identity can be read through the naming practices (Araz, 2015: 97).

Lynch (2010: 120) counts place names among ten basic characteristics of urban form that describe the physical features of residential areas. In order to form a unique identity for a city, citizens must know and adopt it, become familiar with it, and actively participate in its emergence, change and transformation process (Bilgin, 2011: 40). The unifying and separating feature of culture is also valid for place names (Tümertekin and Özgüç, 2019: 163). Mills (2014: 52) defines cities as "the space where remembering and forgetting take place and the tool that provides it". Living down the undesired sections of urban memory and substituting them with others are usually done through place naming (Köşker, 2018: 92). Naming streets, avenues or squares, or any revision, serves to efface a memory or to help reconstructing a history (Araz, 2015: 30). Even if all other remembering elements have disappeared and the people living there have passed away, place names remind us much about history and the past of a place (Tümertekin and Özgüç, 2019: 184).

Once a name is given, the name itself becomes a member of culture, together with the physical structure, architecture, and activities taking place in space, and gains a distinct identity (Gülbetekin, 2017: 69). Therefore, naming the place is always open to ideological reproductions (Özgen, 2018: 117). In this context, post-structuralists examine the discursive structure and characteristics, the forms of discourse that make a particular writing or speech natural and reliable, rather than intentions, beliefs or perceptions (Ar, 2020: 282). They aim to see dominant discourses beyond their naturalized forms so that others that are excluded in representative practices can be envisioned. Moreover, they are concerned with processes by which various discursive structures are constructed, fixed or changed (Aydın-Düzgit, 2015: 156).

"Post-structuralism, which defends that the human subject does not have a holistic consciousness and is basically structured through language, also puts the concepts such as causality, identity, dualism and truth through a strict criticism filter" (Cevizci, 1999). The main reason behind this determination is that there is no singular meaning for facts, the differentiation of this meaning according to time and place, and the strictly attributed meanings do not fully reflect reality (Bilgili, 2017: 102). Therefore, according to the post-structural approach, there is no unifying reality or a traditional, central meaning that limits the meaning of any discourse or text. Because the concept of meaning offers that its boundaries and form are not complete or cannot be defined within a certain form and process. It is far from approaching that meaning is precise, absolute, rigid and static (Parkes, 2012: 1-2).

In this context, one of the most used tools is to analyze the preferred names. Toponomy, which means examining place names in terms of structure, meaning and origin (Eren, 1966: 155), provides valuable information about people in a particular place and their cultures (Tümertekin and Özgüç, 2019: 183). Naming studies tend to be examined linguistically, and different perspectives in this field have come to the fore with critical toponomy studies.

Critical toponomy perceives naming preferences as an action that reflects power relations beyond the linguistic approach (Özberk, 2018: 666). Critical geography tends to view spatial toponomy as part of 
social inequalities, means of pressure, and social engineering (Alderman and Inwood, 2013). According to Turan and Yalçıner-Ercoşkun (2017: 59), critical toponomy studies can be handled from two aspects. The first is to examine what place names mean and remind society. The second is the investigation of the political power and political struggles that run in the background of the practice of meaning and reminder. Rose-Redwood et al. (2009: 458) proposes three different theoretical frameworks that can be used for critical analyzes of urban toponomy: political semiotics, studies of governance, and normative theories of social justice and symbolic resistance.

Although critical toponomy studies in Turkey is limited and mostly rely on with avenues, boulevards and squares. In addition, studies have also been carried out on changed place names especially for villages (Şahin, 2010) or spaces formed after urban transformation projects (Çetin and Şentürk, 2019). In this study, unlike some basic studies in the literature, the relationships between naming preferences of cultural centers within the service area of local governments and the activities carried out in cultural centers are analyzed. Other uses in the campuses of cultural centers and the activities exhibited in these centers are among other important practices in terms of reconstruction and dissemination of cultural identity (Özgen and Sar1, 2021).

\section{Methodology and Material}

In this study, the mixed research method, which is considered as the third approach by Creswell (2003), was used. While the mixed method contributes to establishing a relationship between qualitative and quantitative research methods (Onwuegbuzie and Leech, 2004), it also used for generalizing research results (Johnson and Onwuegbuzie, 2004). While there are three different applications of this method as Trilogy, Explanatory and Exploratory, the Exploratory sequential mixed method was used in this study (Creswell, 2014). Thus, in the field study, the data obtained with an inductive approach were then analyzed in line with the determined purpose (Munhall, 2007: xv) and the statistical significance level of the correlation between both data sets was tested and the comprehensibility of the relevant data was reinforced. In this context, the research was completed in four stages:

In first stage, cultural centers located in the central districts of Ankara (Altındağ, Çankaya, Etimesgut, Gölbaşı, Keçiören, Mamak, Pursaklar, Sincan and Yenimahalle) were determined as the universe of the study. In this context, the web addresses of the municipalities of the 68 cultural centers in the city center of Ankara were determined using the provincial introduction booklets (Ankara Development Agency, 2017; Ankara Governorship, 2013) and the applications of "Google Map" and "Google Planet". These findings were recorded in Microsoft Excel and a preliminary evaluation was made.

In second stage, the structured interview technique was applied to obtain subjective evaluations of the cultural center administrators and the trainees benefiting from these centers (Özgen, 2016: 158).

In third stage, the content analysis technique was used and the qualitative data obtained during the field study were analyzed in depth (Özgen, 2020: 39). In addition, all kinds of visual or verbal elements that function as a communication medium are considered as text (Neuman, 2014: 466; Patton 2014). The texts handled by content analysis are grouped on the basis of certain concepts and themes and presented in a way that can be understood by readers (Yıldırım and Şimşek, 2008). Messages in text; have been 
revealed as a result of a series of processes including comments about the sender, the message itself and the recipient (Weber, 1989: 5). As a result, descriptive situation and content analysis techniques were used in analyzing the research data so that the findings collected through the field study could be transferred to the reader by organizing and interpreting them (Bal, 2016; Baş and Akturan, 2017; Cope, 2005: 224; Özgen, 2016: 186-188).

In forth stage, content analysis was performed and the Chi-square test of independence was used to test whether there was a significant correlation between the 9 basic categories obtained and the sociodemographic characteristics of the participants, and the statistical significance level was accepted as $\mathrm{P}$ $<0.0001$ (Bakan and Büyükbeşe , 2004; Bircan et al., 2003; Güngör and Bulut, 2008).

\section{Findings}

A significant relationship was determined between the political structuring and the name of the cultural centers in districts and the activities carried out there. It has been determined that in Altındağ, Mamak and Pursaklar districts, the priority is given to primarily religious-conservative names and related activities. Nationalist names and related activities come to the fore in Etimesgut District. On the other hand, in Çankaya and Yenimahalle districts, more open and services related with social developments especially in the form of social, cultural and psycho-social axial orientations attract attention. In addition, names and activities that can be defined as more secular and social democrat were heavily expressed in these districts.

Although the political name preferences and the approaches of the cultural center administrators show a certain orientation, it is important to understand the performed activities in the cultural centers, activity types proposed by beneficiaries and effectiveness of these proposals with the perspective of participants. It is observed that visits of participants in Çankaya and Yenimahalle districts to the cultural centers are mostly related to the attainments related to the socio-cultural, artistic and socio-political categories. It was determined that participants who visited the cultural centers in Altındağ, Keçiören, Mamak and Pursaklar districts mostly aimed to reach services under socio-economic and phsyco-social category.

All of these concepts, which reflect the views and opinions of the participants about the cultural centers, are related to the daily life practices. Since the realization of effective services for these concepts is under the control of political ideologies; they are completely ideological. The differences observed between the sampled districts also confirm this approach. All these analyzes have shown that depending on socio-economic conditions of participants, job and employment expectations affect the preferences of the participants who benefit from the cultural centers. However, even in districts where the services for artistic activities, which is one of the main usage purposes of cultural centers, are insufficient, there are demands for receiving more services under this category. In other words, participants who benefit from the cultural center, even though they benefit from the services in the scope and content determined by the local administrations, have also expressed their demands for the change or improvement of these activities. Therefore, it has been determined that the political / ideological approaches preferred in the names of the cultural centers and the activities in these centers widely overlaps and the design of these activities in cultural centers is far from representing multiculturalism and whole society. It should not 
be forgotten that such ideological activities carried out through cultural centers do not serve social integrity and may impair the ability to live together.

\section{Conclusion}

The most important conclusion from the research data is undoubtedly that political ideologies are a practice of their ideologies in cultural centers, and almost all activities designed to ensure a proper environment for the continuation of relevant political ideology. As a result, it was determined in the study that the ideological stance and priorities of local political powers are one of the most important factors in determining the names of places. Local governments use these names as a means of diversification as well as a political / ideological integration which operates concurrently. These naming practices, which are determined without receiving views and considerations of individuals living in the same society having different ethnic, religious, sectarian, belief and political affiliations, are assumed to be unifying for individuals sharing the same ideology with local governments, on the contrary, they have a distinctive role in terms of "others". Therefore, the crystallization of the border between "us" and "other" from an ideological point of view harms the social integrity.

\section{Referanslar/References}

Alderman, D. H., Inwood, J. (2013). Street Naming and the Politics of Belonging: Spatial Injustices in the Toponymic Commemoration of Martin Luther King Jr. Social and Cultural Geography, 14(2), 211-233. doi: $10.1080 / 14649365.2012 .754488$

Aliağaoğlu, A., Uğur, A. (2016). Şehir Coğrafyası. Ankara: Nobel Akademik Yayıncılık.

Althusser, L. (2014). İdeoloji ve Devletin İdeolojik Aygıtları (Çev. A. Tümertekin), İstanbul: İthaki Yayınları.

Ankara Kalkınma Ajansı (2017). Ankara'da Kültür ve Sanat, Ankara: Art15Medya.

Ankara Valiliği (2013). Ankara Tanıtım Kitapçığı. Ankara: Kültür ve Turizm İl Müdürlüğü.

Ar, M. (2020). Jeopolitik Söylemde Paradigmatik Değişim ve Eleştirel Söylem Analizi. International Journal of Geography and Geography Education, (42), 278-290. doi: 10.32003/igge.674834

Araz, S. (2015). Cadde ve Sokak Adlandırmalarının (Kentsel Toponimi) Kentsel Kimlik ve Toplumsal Bellek Üzerindeki Etkilerinin Değerlendirilmesi; Ayvalık ve Cunda Örneği, İstanbul Teknik Üniversitesi, Fen Bilimleri Enstitüsü, Yayınlanmamış Yüksek Lisans Tezi, İstanbul. 20.10.2019 tarihinde https://polen.itu.edu.tr/xmlui/handle/11527/15104 adresinden alınd1.

Aydin-Düzgit, S. (2015). Post-Yapısalcı Yaklaşımlar ve Uluslararası İlişkilerin Temel Kavramları. Uluslararası İlişkiler, 12(46), 153-168.

Bakan, İ., Büyükbeşe, T. (2004). Çalışanların İş Güvencesi ve Genel İş Davranışları İlişkisi: Bir Alan Çalışması. Erciyes Üniversitesi İktisadi ve İdari Bilimler Fakültesi Dergisi. 23, 35-59. 21.11 .2019 tarihinde https://dergipark.org.tr/tr/pub/erciyesiibd/issue/5880/77807 adresinden alınd.

Bal, H. (2016). Nitel Araştırma Yöntem ve Teknikleri (Uygulamall- Örnekli). İstanbul: Sentez Yayınc1lık

Baş, T., Akturan, U. (2017). Sosyal Bilimlerde Bilgisayar Destekli Nitel Araştırma Yöntemleri. Ankara: Seçkin Yayıncılık

Bauman, Z. (2017). Kimlik. (Çev. M. Hazır). Ankara: Heretik.

Baysan, S. (2019). Sosyal Sorumluluk Çalışmaları ve Kültürel Mirasın Sürdürülebilirliği. Nurettin Özgen (Ed.). Sürdürülebilir Kalkınma içinde (256-301), Ankara: Pagem Akademi.

Bilgili, M. (2017). Coğrafyanın Bilimsel Kimliğine Postyapısalcı Bir Yaklaşım. Marmara Coğrafya Dergisi, 35, 101-109. doi: $10.14781 /$ mcd. 291173

Bilgin, N. (2011). Sosyal Düşüncede Kent Kimliği. İdealkent, 2(3), 20-47. 19.09.2019 tarihinde https://dergipark.org.tr/tr/pub/idealkent/issue/36633/417042 adresinden alınd1.

Bircan, H., Karagöz, Y., Kasapoğlu, Y. (2003). Ki-kare ve Kolmogorov Smirnov Uygunluk Testlerinin Simulasyon İle Elde 
Edilen Veriler Üzerinde Karşılaştırılması. Cumhuriyet Üniversitesi İktisadi ve İdari Bilimler Dergisi, 4(1), 69-80. 18.10.2019 tarihinde http://eskidergi.cumhuriyet.edu.tr/makale/166.pdf adresinden alınd1.

Cevizci, A. (1999). Paradigma Felsefe Sözlüğü. İstanbul: Paradigma yayınları.

Cope, M. (2005). Coding Quantitative Data. Qalitative Research Methods. Iain Hay (ed.) Human Geography içinde (223-233). New York: Oxford University Press.

Creswell, J. W. (2003). Research Design: Qualitative, Quantitative, and Mixed Methods Approaches (2nd ed.). Thousand Oaks, CA: Sage.

Creswell, J. W. (2014). Nitel Araştırma Yöntemleri: Beş Yaklaşıma Göre Nitel Araştırma ve Araştırma Deseni (Çev: M. Bütün, S.B. Demir). Ankara: Siyasal.

Cumhuriyet Gazetesi (1994). Uğur Mumcu'yu halk sahiplendi, 7 Ağustos Ulusal Baskıs1.

Çetin, R., Şentürk. A. (2019). Eleştirel Kentsel Toponimi ve Prestijli Mekânlar Yaratmada Kentsel İsimlerin Kullanılması: Fikirtepe Örneği. Megaron Dergisi, 14(1), 133-144. doi: 10.5505/Megaron.2018.05826

Eren, H. (1966). Yer Adlarımızın Dili. Türk Dili Araştırmaları Yıllı̆̆ı - Belleten, 13, 155-165. 20.06 .2020 tarihinde https://dergipark.org.tr/tr/pub/belleten/issue/38302/443259 adresinden alınd1.

Gülbetekin, M. (2017). Mekânın Hafizası: Yer Adları, Ankara: Hitabevi.

Günay-Aktaş, S., Yayla, Ö. (2018). Mekân ve Yaşamsal Örüntüleri. Nurettin Özgen (ed.), Sosyal Coğrafya içinde (227-250), Ankara: Pegem Akademi.

Güngör, M., Bulut, Y. (2008). Ki-Kare Testi Üzerine. Fırat Üniversitesi Doğu Araştırmaları Dergisi, 7(1), 84-89. 27.08.2019 tarihinde https://dergipark.org.tr/tr/pub/fudad/issue/47171/593924 adresinden alınd1.

Johnson, R. B., Onwuegbuzie, A. J. (2004). Mixed Methods Research: A Research Paradigm Whose Time Has Come. Educational Researcher, 33(7), 14-26. doi: 10.3102/0013189X033007014

Köşker, N. (2018). Mekân ve Yer. Nurettin Özgen (ed.), Sosyal Coğrafya içinde (77-108), Ankara: Pegem Akademi.

Lynch, K. (2010). Kent İmgesi (Çev: İ. Başaran), İstanbul: Türkiye İş Bankası Kültür Yayınları.

Madanipour, A. (2013). The Identity of the City. Silvia Sereli (Ed.), Urban and Landscape Perspectives içinde (49-63), Dordrecht: Springer Science+Business Media.

Mai, L. (2016). Doğu Alman Kentlerinde Kültür Şoku ve Kimlik Bunalımı. Ayşe Öncü ve Petra Weyland (Ed.), Mekân, Kültürr, İktidar içinde (107-115). İstanbul: İletişim Yayınları.

Mills, A. (2014). Hafizanın Sokakları: İstanbul' da Peyzaj, Hoşgörü ve Ulusal Kimlik. (Çev: C. Soydemir), İstanbul: Koç Üniversitesi Yayınları.

Munhall, P. L. (2007). A Phenomenological Method. Patricia L. Munhall (Ed.), Nursing Research: A Qualitative Perspective içinde (145-210). Sudbury, MA: Jones and Bartlett.

Neuman, W. L. (2014). Toplumsal Araştırma Yöntemleri 2. Cilt (Çev: S.Özge). Ankara: Siyasal Kitabevi.

Onwuegbuzie, A. J., Leech, N.L. (2004). Enhancing the Interpretation of "Significant" Findings: The Role of Mixed Methods Research. The Qualitative Report, 9(4), 770-792. doi: 10.46743/2160-3715/2004.1913

Öncü, A., Weyland, P. (2016). Küreselleşen Kentlerde Yaşam Alanı ve Toplumsal Kimlik Mücadeleleri. Ayşe Öncü ve Petra Weyland (Ed.), Mekân, Kültür, İktidar İçinde (9-39). İstanbul: İletişim Yayınları.

Özberk, N. (2018). Mekânsal Semiyotik ve Politik Semantik Açısından Kentsel Metnin Dönüşümü: Nevşehir'de Kamusal Mekân İsimlendirmeleri Örneği. İdealkent, 9(24), 662-700. doi: 10.31198/idealkent.432225

Özgen, N. (2016). Nitel Araştırmalarda Verilerin Toplanması ve Analizi. Nurettin Özgen (Ed.), Beşeri Coğrafyada Araştırma Yöntemleri ve Teknikler içinde (157-198). Ankara: Pegem Akademi.

Özgen, N. (2018). Kimlik-Toplumsal Eşitsizlik ve Ayrımcılık. Nurettin Özgen (Ed.) Sosyal Coğrafya içinde (109-172), Ankara: Pegem Akademi.

Özgen, N. (2020). Ortadoğu Kavramına Yönelik Zihinsel Tasarımlar. Coğrafya ve Coğrafya Eğitimi Dergisi (41), 36-58. doi: 10.32003/igge.653501

Özgen, N., Sarı, V. İ. (2021). Siyasal İdeolojiler Bağlamında Mekân İsimlendirmeleri: Ankara'daki Kültür Merkezleri Örneği. Ankara Araştırmaları Dergisi, 9(1). doi: 10.5505/jas.2021.73745

Parkes, R. J. (2012). What is Poststructuralism? Academic Bytes. 
Patton, M. Q. (2014). Nitel Araştırma ve Değerlendirme Yöntemleri (Çev. M. Bütün ve S.B. Demir), Ankara: Pegem Akademi.

Rose-Redwood, R., Alderman, D. ve Azaryahu, M, (2010). ). Geographies of Toponymic Inscription: New Directions in Critical Place-Name Studies, Progress in Human Geography. 34(4), 453-470. doi: 10.1177/0309132509351042

Sanayi ve Teknoloji Bakanlığı (2019). İlçelerin Sosyo-Ekonomik Gelişmişlik Sıralaması Araştırması (SEGE-2017), Ankara: Kalkınma Ajansları Genel Müdürlüğ̈̈.

Şahin, G. (2010). Türkiye'de Yapılmış Toponomi Çalışmaları. Adıyaman Üniversitesi Sosyal Bilimler Enstitüsü Dergisi, 4, 134-156. 26.10.2019 tarihinden https://dergipark.org.tr/tr/pub/adyusbd/issue/1399/16546 adresinden alınmıştır.

Şeker, M., Bakış, Ç., Dizeci, B. (2018). İnsani Gelişme Endeksi-İlçeler: Tüketiciden İnsana Geçiş. İstanbul: İnsani Gelişme Vakfi.

Tekeli, İ. (2009), Modernizm, Modernite ve Türkiye’nin Kent Planlama Tarihi, Ankara: Tarih Vakfi Yurt Yayınları.

Turan, S., Yalçıner-Ercoşkun, Ö. (2017). Meydanlardaki İsim Değişikliklerinin Kent Belleğine Etkisi: Ankara Örneği. Mimarlık Bilimleri ve Uygulamaları Dergisi, 2(1), 55-68. doi: 10.30785/mbud.337234

Tümertekin, E., Özgüç. N. (2019). Beşerî Coğrafya: İnsan Kültür Mekân. İstanbul: Çantay Kitabevi (18.Baskı).

Ünlü, T. S. (2017). Kent Kimliğinin Oluşumunda Kentsel Bellek ve Kentsel Mekân İlişkisi: Mersin Örneği. Planlama; 27(1), 75-93. doi: 10.14744/planlama.2017.06078

Weber, R.P. (1989). Basic Content Analysis. London: Sage Books.

Yıldırım, A., Şimşek, H. (2013). Sosyal Bilimlerde Nitel Araştırma Yöntemleri. Ankara: Seçkin Yayıncılık. 